\title{
MOMENTO EN QUE EL EMBRIÓN ES PERSONA HUMANA
}

\author{
José Joaquín Ugarte Godoy
}

El autor inquiere cuándo comienza el sujeto biológico hombre. La respuesta es que al momento de la fecundación, porque desde ese momento el cigoto cuenta con el código genético humano que le permite, sin inyección de nueva información, alcanzar el pleno desarrollo. El autor sostiene que la fecundación tiene como evento definitorio la penetración de la cabeza del espermatozoide en el ovocito, y expone las respuestas que se dan a las objeciones que han merecido estos planteamientos. Luego aborda el aspecto filosófico del problema: toma la noción del alma de Aristóteles y concluye que si hay sujeto biológico hombre desde la fecundación, tiene que estar en él el alma humana desde ese mismo momento. Por último el autor expone las tres respuestas filosóficas que se han dado a esta cuestión: a) que el desarrollo del embrión se debe a una potencia formativa del alma del padre que se traslada al embrión, y que lo va transformado primero en vegetal, luego en animal y finalmente en hombre, que es la doctrina de Aristóteles y Santo Tomás; b) que el embrión tiene los órganos del adulto en miniatura, siendo el desarrollo sólo crecimiento, que es la tesis preformista del siglo XVII, y c) que el embrión tiene su propia facultad organogénica que le permite, a partir de una organicidad básica, construir él mismo sus órganos definitivos, tesis que ha tenido sostenedores desde la Grecia antigua hasta hoy.

José Joaquín Ugarte Godoy. Profesor de Derecho Civil y de Filosofía del Derecho en la Pontificia Universidad Católica de Chile. 


\section{ASPECTO BIOLÓGICO: \\ EL COMIENZO DEL SUJETO BIOLÓGICO HOMBRE}

a) Cigoto y código genético

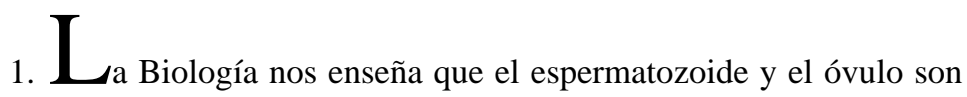
células que participan fundamentalmente por igual en la generación: cada una contiene veintitrés cromosomas, uno de ellos determinante del sexo; y que producida la fecundación, fusionados el espermatozoide y el óvulo en la nueva célula llamada "huevo" o "cigoto", que posee cuarenta y seis cromosomas como todas las células del cuerpo humano que no sean las generativas, se tiene el embrión que inicia una vida propia con un proceso de división y diferenciación celular, de organización corporal, que culmina en el feto de órganos completamente formados.

También nos enseña la Biología ahora que cada cromosoma de las células germinales tiene un abundante número de genes, que son fragmentos de distinto tamaño de ADN (ácido desoxirribonucleico), ácido que se compone de ácido fosfórico en fosfatos, de deoxirribosa, que es un azúcar de cinco carbonos, y de bases nitrogenadas. Las bases nitrogenadas son la adenina (A) y la guanina (G), que son las bases púricas, y la timina (T) y la citosina (C), que son las bases pirimídicas. El fosfato, la desoxirribosa y una de las bases mencionadas se unen para constituir un nucleótido, y los nucleótidos, a su vez, se unen para formar el ADN, que resulta ser, entonces, un polinucleótido o cadena de nucleótidos. En ellos se repiten las moléculas de desoxirribosa y fosfatos, y varían las bases nitrogenadas. Tres bases sucesivas constituyen lo que se llama un tripleto, entidad que rige la síntesis de un determinado aminoácido. Los aminoácidos — que son veinte-, según el orden de secuencia en que se hallen, constituyen las diversas proteínas, las substancias con las que se construye el organismo, cada una de las cuales tiene una función en el mismo. Hay sesenta y cuatro tripletos, número que resulta de la combinación de a tres, en los diversos órdenes posibles, de las bases nitrogenadas. Cada gen, según el orden y número de sus tripletos, produce una determinada proteína, y se define e individualiza precisamente por su capacidad para ello.

En la secuencia de las bases reside la llamada información genética. El conjunto de la información genética es el código genético o genoma, que es la suma de todos los genes. 
b) El código genético es responsable de todo el desarrollo cualitativo y cuantitativo hasta la formación de los órganos definitivos

2. Se ha demostrado que en el código genético se encuentra programado totalmente el nuevo ser. El genoma es responsable de todo su desarrollo cualitativo, llamado morfogénesis, y de todo su desarrollo cuantitativo, sin perjuicio de las modalidades que pueda producir el ambiente.

"Este genoma - dice el profesor Angelo Serra- en el cual, para usar una comprensible analogía, está escrito el plano y el programa de desarrollo de un nuevo sujeto humano, representa la estructura dinámica necesaria, aun cuando no suficiente, para el desenvolvimiento ordenado, e intrínsecamente orientado y gobernado del nuevo sujeto hasta la clausura de su ciclo vital"1.

En el mismo sentido, se lee en la obra Embriología Básica de Patten:

Al final de cuentas, cada uno de los muchos tipos celulares del cuerpo adulto desciende de una sola célula: el huevo fecundado. Este hecho implica reconocer que toda la información que se requiere para generar esta diversidad celular está presente en el cigoto $^{2}$.

En otro pasaje de la misma obra, explicando el autor el influjo de la herencia y del medio, nos dice: "Son de importancia vital en el desarrollo, aunque en forma muy diferente. La herencia establece el potencial inherente del sistema de desarrollo de un individuo, en tanto que el medio estima qué tan lejos puede ir el individuo para desarrollar esta herencia plenamente"3.

O sea, el medio sólo estimula el desarrollo de lo que está en el cigoto y en el embrión, recibido por herencia.

Por su parte, dice el célebre biólogo francés Jacques Monod, Premio Nobel 1965 de Fisiología y Medicina, a propósito de la antigua disputa de epigenistas y preformistas — según los primeros, el embrión se iba formando por etapas, y según los segundos, estaba ya formado en miniatura desde el principio:

\footnotetext{
${ }^{1}$ Angelo Serra, "Dalle Nuove Frontiere della Biologia e della Medicina: Nuovi Interrogativi alla Filosofia, al Diritto e alla Teologia”, 1990, p. 71. Angelo Serra es Director del Instituto de Genética Humana y del Servicio Clínico de Citogenética de la Universidad del Sacro Cuore de Milán.

${ }^{2}$ Patten: Embriología Básica (Bruce M. Carlson, ed.), 1990, pp. 324-325.

${ }^{3}$ Ibídem, p. 40.
} 
Este análisis se ve reducido a una disputa verbal desprovista de todo interés: la antigua querella de los preformacionistas y de los epigenistas. La estructura acabada no estaba en ninguna parte, como tal, preformada. Pero el plan de la estructura estaba presente en sus mismos constituyentes. Ella puede realizarse de forma autónoma y espontánea, sin intervención exterior, sin inyección de nueva información.

[...]

La información estaba presente, pero sin expresar en los constituyentes. La construcción epigenética de una estructura no es una creación, es una revelación ${ }^{4}$.

\section{El eminente biólogo francés Jean Rostand escribe:}

Desde el instante de su concepción, el ser está particularizado, individualizado, posee una personalidad potencial. Y el hecho de que dos individuos humanos se parezcan tanto cuando han recibido el mismo patrimonio (verdaderos gemelos) nos indica en seguida la importancia de esta particularización, de esta individualidad hereditaria 5 .

Jérôme Lejeune, el famoso genetista francés que descubrió la causa del síndrome de Down (mongolismo), dice sobre este punto:

Al principio, cuando el ser comienza su andadura, es la información genética la que, exceptuando los accidentes, determina todas sus cualidades. Según la afortunada fórmula de los matemáticos, el ser llamado a la vida se encuentra como reducido a su más simple expresión [...]. Aquí es necesario resaltar que la "esencia" precede a la "existencia". En efecto, el mensaje codificado del ADN será transcrito al ARN (ácido ribonucleico), que, a continuación, será rehecho. Secundariamente, las proteínas que son las máquinas - herramientas de la célula- serán construidas de acuerdo con el código del ARN mensajero. Esto quiere decir que dadas, de un lado, la máquina de traducir (el citoplasma) y, de otro, la fórmula del ADN (el núcleo y sus cromosomas), se podría conocer exactamente la "esencia" del nuevo ser, aún antes que se haya expresado, es decir, antes de que la existencia sea reconocible".6.

Uno de los descubrimientos más importantes del último tiempo es el de los genes reguladores de la morfogénesis. Se ha estudiado especialmente en la Drosophila la génesis del llamado "diseño global anatómico de la

${ }^{4}$ Monod, Jacques: El Azar y la Necesidad. Ensayo sobre la Filosofía Natural de la Biología Moderna, 1971, p. 100.

${ }^{5}$ Rostand, Jean: El Hombre, 1983, p. 48. El libro tiene el título original L' Homme, y fue publicado por Ediciones Gallimard, París, 1941.

${ }^{6}$ Lejeune, Jérôme: “Una Reflexión Ética sobre la Medicina Prenatal”, 1993, p. 262. 
especie", distinguiéndose en la Drosophila adulta diversos segmentos esbozados ya en el embrión. Tres clases de genes intervienen en la organización de los segmentos: a) los de polaridad global, que determinan el diseño corporal en cuanto a su polaridad anteroposterior y dorsoventral, por ejemplo, formando gradientes espaciales de concentración de substancias que van determinando el destino de las células según su posición; b) los genes de segmentación, que producen los primordios de los segmentos, influyendo unos sobre regiones amplias, correspondientes a varios segmentos, determinando otros los segmentos, y otros definiendo la identidad de sus partes anteriores y posteriores, y c) los genes de especialización de cada segmento, llamados homeóticos, que determinan las estructuras que se producirán desde la cabeza hasta el final del abdomen, constituyendo su secuencia el diseño corporal de la Drosophila.

Cada órgano tiene un "subprograma" propio de diferenciación celular en que intervienen múltiples genes específicos. Los genes homeóticos deciden qué genes han de expresarse de modo que se lleva a cabo uno u otro subprograma.

En 1984 se descubrió la secuencia del ADN llamado "homeo", que sería la más importante en la clase de los genes homeóticos, productores de las proteínas homeóticas, que regularían la trascripción de genes?

Se estima en decenas de miles la cantidad de genes que dirigen el desarrollo de los mamíferos ${ }^{8}$.

Los genes homeóticos en el hombre están localizados, entre otros, en los cromosomas 2, 7, 12 y 17 - dice Serra. Este autor expone la clasificación de los genes reguladores de la morfogénesis en: a) genes posicionales, que determinan la información posicional de las células a lo largo de los ejes anterior-posterior y dorso-ventral del embrión, y actúan produciendo moléculas que se denominan "morfogenes", las que se distribuyen en forma asimétrica en el embrión; b) genes selectores, que rigen la secuencia temporal y la diferenciación espacial de los diversos segmentos y campos a lo largo de los mencionados ejes, hallándose tales genes reagrupados en las familias de los llamados genes homeóticos, y c) los genes estructurales, que, determinados por los anteriores, producen la diferenciación y ensamblaje de las células que forman los tejidos correspondientes ${ }^{9}$.

${ }^{7}$ Rubio Cardiel, Julián: Los Genes: Qué Son y qué Hacen en el Organismo, 1989, pp. 129-143.

${ }^{8}$ Serra, Angelo: "El Estado Biológico del Embrión Humano", 1996, p. 585.

${ }^{9}$ Ibídem, pp. 586-587. 


\section{c) La individualidad del código genético o genoma}

3. "El cigoto - dice Angelo Serra - posee un genoma absolutamente único que 1) le confiere una entidad humana; 2) lo distingue de cualquier otro, y 3) constituye la estructura fundamental permanente necesaria para el desarrollo rigurosamente orientado del nuevo sistema" [...] "un cuidadoso análisis molecular del genoma demostraría su 'singularidad' para cada cigoto: singularidad genómica que, siendo permanente, se puede correctamente tener como un marcador de la identidad e individualidad biológica de un cigoto dado" ${ }^{10}$.

4. Lejeune explica, en cuanto a la individualidad que produce el genoma, que son diferentes los mensajes transmitidos por el padre y por la madre, y que una misma persona no transmite la misma información, exactamente, en cada uno de sus espermatozoides o de sus óvulos, de todo lo cual resulta que cada genoma es completamente típico del respectivo ser humano, de modo que nunca se ha dado antes y nunca se volverá a dar después: es "una novedad absoluta"11.

Hoy, añade Lejeune, la unicidad de cada ser humano, que era antes una deducción de lo que se sabía sobre genes y una conclusión estadística, ha sido demostrada experimentalmente por el descubrimiento de Jeffreys, en Inglaterra.

Jeffreys escogió una porción pequeña de ADN con una información que se repite múltiples veces en muchos cromosomas distintos, y que puede ser un mensaje de regulación, que determine qué actúa y qué no, en las células. Este mensaje puede tener muchos cambios minúsculos.

Pues bien, estos genes son tantos, y ofrecen tantas variaciones, que constituyen un conjunto claramente reconocible en cada uno. En la prueba de Jeffreys, se pone el ADN en solución y se hace migrar a un medio especial, y entonces se ve - dice Lejeune- algo semejante al código de barras de un supermercado. Cada individuo tiene su propio "código de barras", que lo diferencia de los demás, de modo que la probabilidad de encontrar dos individuos con idéntico código es menos que una entre mil millones $^{12}$.

\footnotetext{
${ }^{10}$ Serra, Angelo: "Dalle Nuove Frontiere...”, 1990, pp. 70-71.

${ }^{11}$ Lejeune, Jérôme: ¿Qué Es el Embrión Humano?, 1993, p. 36.

${ }^{12}$ Lejeune, Jérôme: ¿Qué Es el Embrión Humano?, 1993, pp. 47-49.
} 
d) Momento en que se origina el cigoto

5. Para la fecundación el espermatozoide debe pasar la llamada zona pelúcida — capa de glucoproteínas que rodea al óvulo-, lo que es posible con ayuda de enzimas que libera el acrosoma, capa que cubre la mitad de la superficie del núcleo de la célula masculina. Una vez que el espermatozoide penetra en el ovocito, se produce la llamada "reacción de zona", que cambiando la permeabilidad de la zona pelúcida impide que otros espermatozoides entren al ovocito, es decir, impide la poliespermia o fecundación por varios espermatozoides, que trae como consecuencia la interrupción temprana del desarrollo del embrión y, en definitiva, su muerte ${ }^{13}$.

La impermeabilización de la zona pelúcida hace que los espermios que llegan después queden atrapados en esa barrera protectora.

El cambio de permeabilidad de la zona pelúcida tiene lugar porque el contacto de la cabeza del espermatozoide con la superficie del ovocito causa la liberación de determinadas substancias e inactiva los sitios de la zona pelúcida destinados a recibir a los espermatozoides ${ }^{14}$.

La penetración del espermatozoide en el ovocito, que es la fusión de los gametos o singamia, produce además de la impermeabilización mencionada, la reanudación de la segunda división meiótica del ovocito de la cual resultan el ovocito definitivo y el segundo cuerpo polar ${ }^{15}$; y produce también la activación metabólica del ovocito. El ovocito definitivo tiene veintitrés cromosomas que se hallan en lo que se denomina el pronúcleo femenino.

El espermatozoide, después de penetrar en el ovocito, avanza hacia el pronúcleo femenino. Su núcleo se hincha y se convierte en el llamado pronúcleo masculino. La cola del espermatozoide se desprende y degenera. Se aproximan los pronúcleos masculino y femenino, y se duplica su ADN en preparación de la primera división del cigoto. Los cromosomas se condensan en los pronúcleos. Luego viene el acercamiento de estos últimos, que en el hombre $-\mathrm{y}$ en los mamíferos en general, a diferencia de lo que sucede en otras especies- no se fusionan directamente formando un núcleo único, sino que conservan su individualidad hasta después de la ruptura de sus membranas nucleares ${ }^{16}$. Al desintegrarse las membranas, los cro-

${ }^{13}$ Patten: Embriología Básica (Bruce M. Carlson, ed.), 1990, p. 129.

${ }^{14}$ Langman: Embriología Médica (Thomas W. Sadler, ed.), 1993, p. 42.

${ }^{15}$ Las divisiones meióticas de las células germinales, que son dos, tienen por objeto reducir el número de sus cromosomas y la cantidad de ADN para que entre la célula germinal masculina y la femenina juntas tengan la dotación que debe poseer el cigoto, y no una doble.

${ }^{16}$ Alberts, Bruce y otros: Molecular Biology of the Cell, 1994, p. 1033. 
mosomas, que ya son cuarenta y seis, se disponen linealmente en el ecuador de la célula, lo que constituye la cariogamia, para la división del cigoto en dos células hijas. Esta división será la común de las células no germinales, sin reducción del ADN ni del número de cromosomas, es decir, una mitosis o división mitótica. Alineados los cromosomas en el ecuador de la célula, quedan unidos, cada uno por un a modo de filamento, llamado microtúbulo, a los centríolos, corpúsculos que se encuentran uno en cada polo, y así forman una figura que semeja un huso, y se denomina huso mitótico, porque se produce en toda mitosis o división celular corriente; siendo los extremos del huso los centríolos, y su parte gruesa del medio la línea ecuatorial de cromosomas, cada uno con dos partes llamadas cromátidas, unidas en un punto que es el centrómero.

A continuación los veintitrés cromosomas paternos y los veintitrés cromosomas maternos se dividen en el centrómero. Las cromátidas hermanas se van hacia los polos opuestos como en cualquier división mitótica y luego se divide el citoplasma ${ }^{17}$.

Es importante destacar que cuando los pronúcleos aún no se han acercado, y mientras en ellos se condensan los cromosomas, ya se forma el huso mitótico, es decir, está en marcha la primera división del cigoto en dos células, lo que significa que el cigoto existe como tal, como célula única resultante de la unión de los gametos — puesto que se divide en dos- antes del acercamiento de los pronúcleos o cariogamia ${ }^{18}$.

6. Patten define y describe la fecundación como un proceso y no un solo fenómeno, que incluye: 1) contacto inicial de la membrana entre el huevo y el espermatozoide; 2) entrada de la célula espermática en el huevo; 3) prevención de la polierpermia (ingreso de más de una célula espermática en el huevo), y 4) formación y fusión de los pronúcleos masculino y femenino, que lleva a la división final de la segmentación ${ }^{19}$.

Pero cabe preguntarse en qué momento se tiene ya — comienza- la nueva célula, es decir, el huevo o cigoto.

Angelo Serra nos dice al respecto que apenas penetra la cabeza del espermatozoide en el citoplasma del ovocito, tiene comienzo una cadena de

17 Langman: Embriología Médica (Thomas W. Sadler, ed.), 1993, p. 43; Patten: Embriología Básica (Bruce M. Carlson, ed.), 1990, p. 142.

18 "Los cromosomas masculinos y femeninos se condensan separadamente mientras un orden bipolar de microtúbulos señala los polos del primer huso mitótico en desarrollo" (Simerly, Calvin, Wu, Owo-Yang, Zoran, Sara y otros: "The Paternal Inheritance of the Centrosome, the Cell's Microtubule-Organising Center, in Humans, and the Implications for Infertility", 1995, p. 47.

${ }^{19}$ Patten: Embriología Básica (Bruce M. Carlson, ed.), 1990, p. 124. 
actividad que indica con evidencia que ya no son dos sistemas que operan independientemente el uno del otro, sino que se ha constituido un "nuevo sistema" que comienza a operar como una unidad, llamada precisamente "cigoto" o "embrión unicelular" ${ }^{20}$. Se refiere a la impermeabilización de la zona pelúcida, a la activación metabólica del ovocito y al término de la segunda división meiótica del mismo.

El cigoto se forma, entonces, con la penetración del espermatozoide en el óvulo y en ese momento, y no en el momento final del acercamiento de los pronúcleos y la cariogamia ${ }^{21}$.

El médico y filósofo chileno doctor Alejandro Serani parece llegar a la misma conclusión:

"Ahora bien — se pregunta—, ¿qué es el cigoto a partir del cierre de la zona pelúcida?" Y responde: "Se trata sin lugar a dudas de una célula única rodeada de membrana, metabólicamente activa. El espermatozoide como tal ya no existe, y el ovocito original se encuentra importantemente modificado, sobre todo luego del fin de la segunda división meiótica",22.

7. En este punto es preciso prevenir al lector contra una disyuntiva mal planteada, a propósito del momento fundamental o constitutivo de la fecundación, y que consiste en querer elegir entre "fusión de las membranas" y "fusión de los pronúcleos". Decimos que este planteamiento es errado porque, por una parte, la fusión de las membranas no es sino un requisito que normalmente — según el orden natural de las cosas - debe darse para que el espermatozoide penetre en el citoplasma del ovocito, pero lo esencial, lo que en definitiva importa es esa penetración, y, por otra parte, en la especie humana y en los mamíferos en general, como hemos visto, no existe fusión de los pronúcleos en un núcleo único, sino un acercamiento de ellos y posterior alineación de los cromosomas paternos y maternos al ecuador de la célula para la primera división del cigoto.

Los autores separan nítidamente el momento de la fusión de las membranas y el de la penetración del espermatozoide en el ovocito.

"Después de la fusión" — dice el libro Molecular Biology of the Cell - "el espermio es tirado de cabeza adentro del huevo al ser reabsorbidas las microvellosidades" 23 .

${ }^{20}$ Serra, Angelo: "Dalle Nuove Frontiere...”, 1990, pp. 69-70.

${ }^{21}$ Angelo Serra señala que la singamia propiamente dicha es la penetración de la cabeza del espermatozide en el óvulo o fusión, y no la cariogamia, o sea "el acercamiento ordenado de los cromosomas al ecuador de la célula", "llamado tal vez impropiamente singamia". (Serra, Angelo: "Per un'Analisi Integrata dello Status dell' Embrione Umano", 1993, p. 62).

${ }^{22}$ Serani Merlo, Alejandro: “Análisis Antropológico-Ético de la Intervención Genética en los Primeros Estadios del Desarrollo Embrionario", pp. 14-15.

${ }^{23}$ Alberts, Bruce y otros: Mollecular Biology of the Cell, 1994, p. 1032. 


\section{e) Características del desarrollo embrionario que postulan un sujeto biológicamente único}

8. Angelo Serra señala tres características fundamentales del desarrollo embrionario que suponen necesariamente unicidad del sujeto, es decir, que haya un único e idéntico sujeto a través de todo ese desarrollo. Estas características son la coordinación, la continuidad y la gradualidad. Veámoslas.

i) Coordinación. En el desarrollo, que se inicia con la fecundación, se dan una sucesión y una interacción coordinadas de actividad celular y molecular, controladas por el programa de la información del genoma, y según estímulos que llegan constantemente del ambiente extracelular. Ahora bien, esta coordinación del proceso de desarrollo supone un control único, el que a su vez exige un sujeto único.

ii) Continuidad. El desarrollo es un proceso ininterrumpido: cada hecho particular, por ejemplo — dice Serra - la replicación celular, la aparición de los esbozos de los miembros y de los órganos, es "expresión instantánea de una sucesión ininterrumpida y continua en el tiempo de eventos infinitesimales concatenados el uno con el otro sin solución". Pero esta continuidad supone también que el ser en desarrollo sea el mismo al principio del proceso, a través de él y a su término.

iii) Gradualidad. La forma definitiva - dice Serra - se alcanza gradualmente, siendo precedida de un número mayor o menor de formas simples. Y esto supone, necesariamente, que el desarrollo tenga una regulación intrínseca al embrión que lo ordene a alcanzar la forma definitiva; lo cual, a su vez, exige un sujeto único a través de todo el desarrollo, desde su inicio hasta su término ${ }^{24}$.

\section{f) Conclusión: el individuo humano comienza con la fecundación}

9. Expuestas las tres características del desarrollo embrionario que hemos dejado anotadas, la conclusión no puede ser sino que el organismo humano, el cuerpo humano, comienza con la fecundación. A la misma conclusión se llega también considerando que en el cigoto está todo lo que es determinante para el desarrollo cualitativo y cuantitativo que experimenta ese embrión unicelular desde el estadio de tal hasta el de individuo

${ }^{24}$ Serra, "Dalle Nuove Frontiere...”, 1990, pp. 76-79. 
adulto con los órganos definitivos perfectamente constituidos: verdad que ningún biólogo niega. Si el embrión no es ser humano desde el estado de cigoto, tendrá que haber en él un cambio de naturaleza biológica debido a una causa exterior que lo transformase de no humano en humano, añadiéndole algo a tal efecto.

Pero no hay dato alguno que permita suponer la existencia de tal causa, ni se sabe de ningún biólogo que la afirme o insinúe siquiera. No hay ninguna hipótesis propuesta para explicar la citodiferenciación y la morfogénesis que las atribuya a causas determinantes extrínsecas al cigoto.

El embrión es, pues, ser humano, individuo humano, desde el inicio del cigoto. Esto es lo que puede apreciar la Biología: el comienzo del organismo, del cuerpo, del individuo que ella conoce como hombre. La apreciación de si hay o no persona humana no corresponde ya a la Biología, sino a la Filosofía, pues el concepto de persona, y el de alma espiritual, que es lo que hace al hombre ser a más de individuo persona, son conceptos filosóficos. De la personalidad del embrión nos ocuparemos, por eso, en el apartado siguiente ${ }^{25}$.

10. Jérôme Lejeune expresó la conclusión de que el ser humano comienza con la concepción en los siguientes términos:

Tan pronto como los veintitrés cromosomas paternos se encuentran con los veintitrés cromosomas maternos, está reunida toda la información genética necesaria y suficiente para determinar cada una de las cualidades innatas del nuevo individuo. Así como la introducción de un minicasete en un magnetófono en marcha permite la reproducción de la sinfonía grabada, la información contenida en los cuarenta y seis cromosomas (los minicasetes de la música de la vida) resultará descifrada por la maquinaria del citoplasma del huevo fecundado (el magnetófono), y el nuevo ser empieza a manifestarse tan pronto como queda concebido: Que el niño deba después desarrollarse durante nueve meses en el vientre de la madre, no

25 “[...] la conclusión que lógicamente se sigue es que con la fusión de los gametos una nueva célula humana dotada de una nueva estructura informacional comienza a actuar como una unidad individual tendiente a la completa expresión de su dotación genética, que se manifiesta en una totalidad que se organiza en forma constante y autónoma hasta la formación de un organismo completo. Esta 'nueva célula humana' representa, pues, la estructura corpórea de un nuevo ser humano y el momento en el cual este nuevo ser humano comienza su propio ciclo vital. Ciclo vital que, dadas todas las condiciones internas y externas suficientes y necesarias, proseguirá a través de un gradual desarrollo durante el cual el nuevo ser realizará sus inmensas potencialidades, según una ley ontogenética y un plano unificador intrínsecos, conservando permanentemente su propia identidad e individualidad" (Serra, "Dalle Nuove Frontiere...”, 1990, p. 79) 
cambia estos hechos. La fecundación extracorpórea demuestra que el ser humano comienza con la fecundación.

[...]

Tal afirmación no es una hipótesis de un teórico, ni siquiera la opinión de un teólogo, sino una constatación experimental ${ }^{26}$.

La misma conclusión se contiene en los textos de Jacques Monod y de Jean Rostand citados en el párrafo $2^{\circ}$ de este estudio.

\section{Objeciones y su refutación}

\section{Objeción $N^{\circ}$ 1: El individuo humano comienza con la fusión de} los pronúcleos, porque antes no se ha unificado el material genético.

Desde luego, hay que recordar que en el hombre no hay fusión de los pronúcleos en el sentido de formación de un núcleo único, como ya se explicó.

El doctor Serani refuta esta objeción haciendo ver que no hay ninguna diferencia esencial en el hecho de que el material genético se encuentre alineado y apareado en el huso mitótico. De hecho el material genético está disperso en miles de células del organismo durante la interfase celular, es decir, entre dos divisiones mitóticas. Además, la trascripción del ADN, de la que parecen depender las primeras segmentaciones, empezaría "aún antes que los cromosomas se encuentren alineados en metafase" ${ }^{\text {"27. }}$

Pensamos que el hecho de que antes de la cariogamia se haya duplicado por los probúcleos el ADN para la primera división mitótica del cigoto, demuestra que éste ya existe como tal, pues los pronúcleos actúan como un todo para una operación propia del conjunto (véase el número 5 de este trabajo).

Angelo Serra nos dice que la cadena de actividad iniciada apenas penetra la cabeza del espermatozoide en el citoplasma del ovocito - consistente en la impermeabilización de la zona pelúcida, el término de la segunda división meiótica del ovocito y su activación metabólica-, de-

${ }^{26}$ Lejeune, Jérôme: "Genética, Ética y Manipulaciones", conferencia editada por la Universidad Católica de Córdova, 1986; citada por Domingo Basso O. P., Nacer y Morir con Dignidad. Bioética, 1991, p. 85.

${ }^{27}$ Serani, Alejandro: "Análisis Antropológico-Ético de la Intervención Genética en los Primeros Estadios del Desarrollo Embrionario", pp. 15-16. El ADN dirige y produce la síntesis de las proteínas en el citoplasma. Para ello, el ADN es transcrito a ARN (ácido ribonucleico) heterogéneo en el núcleo, para ser procesado y transferido al citoplasma, al ARN mensajero, "que es la copia fiel de la codificación genética de una proteína". En el citoplasma, mediante el ARN ribosomal y el de transferencia, sigue el proceso hasta culminar en la síntesis de la proteína de que se trate. (Horvart y Weiss: Nociones de Biología IV, 1984, p. 78). 
muestra que ya estamos frente a un solo sistema, a una sola célula, el cigoto (Dalle Nuove Frontiere..., pp. 69-70.)

12. Objeción $N^{\circ}$ 2: El individuo humano comienza con la implantación.

El doctor Serani manifiesta que no ha encontrado en los autores que sustentan esta tesis una explicación biológica de la misma. Ni el contacto físico con el útero — añade- ni la conexión sanguínea con la madre podrían explicar la transformación de un simple tejido humano en individuo humano $^{28}$.

Esta objeción, para algunos, al parecer, es ajena a la calidad biológica intrínseca del embrión, y se funda en la no viabilidad que le afecta si la implantación no se produce ${ }^{29}$.

13. Para el ginecólogo F. Abel —según refiere Angelo Serra-, existiría una información extracigótica, proveniente de la madre, a la que el embrión accedería con la implantación, la cual sería imprescindible para constituir en ser humano, a lo que hasta entonces no sería sino "un programa genético humano con sólo potencial teórico y estadístico de alcanzar a ser miembro de la comunidad humana".

El profesor Serra refuta esta opinión argumentando que el programa de desarrollo comienza a actuar con la fecundación, sin perjuicio de que en los placentados se requiera de la coexistencia del embrión con la madre en el primer período de desarrollo embriofetal.

Lo que hay que ver, añade Serra, es si tal coexistencia es esencial o constitutiva para el nuevo ser. Y responde que no lo es, como lo demuestran: a) la independencia del embrión para su desarrollo respecto de la madre en gran parte del reino animal; b) los experimentos de gestación de vertebrados fuera de la madre realizados en los últimos años, la que ha tenido éxito en ratones, por ejemplo, hasta cerca de la mitad del período de desarrollo, etc., lo cual demuestra que la implantación ni produce un "salto cualitativo" ni es indispensable para que se constituya el respectivo animal, conclusión que resulta aplicable al hombre.

A esto añade Serra las siguientes consideraciones: 1) La coexistencia del embrión con la madre comienza mucho antes de la implantación: las trompas alimentan al embrión produciendo proteínas; 2) en el proceso de implantación participan activamente tanto el embrión como la madre: la

${ }^{28}$ Serani, Alejandro: "Análisis Antropológico-Ético de la Intervención Genética en los Primeros Estadios del Desarrollo Embrionario", p. 16.

${ }^{29}$ Véase al respecto la carta de Stephen Lovell al director de la revista Nature, Vol. 314, 11 de abril de 1985, p. 492. 
adherencia del embrión al endometrio de la madre se hace por la interdigitalización de microvellos que se forman en las correspondientes células del embrión, y en las epiteliales del endometrio de la madre, y las células trofoblásticas del embrión fagocitan luego a las epiteliales y a continuación vienen otros procesos merced de los cuales el embrión genera las condiciones apropiadas para seguir su formación y crecimiento; 3) la coexistencia no es jamás pasiva por parte del embrión, el que se comporta "como una unidad que manda sus mensajes y estímulos a otra unidad, la cual ante ellos reacciona y responde, enviando también a su vez los propios mensajes y estímulos", y 4) todo lo anterior demuestra que hay una interdependencia entre la madre y el embrión, la que no suprime la autonomía de ninguno de ellos ${ }^{30}$.

A propósito de la posibilidad de desarrollo del embrión fuera del claustro materno, podemos citar también al Profesor John B. Jenkins, que dice lo siguiente:

[...] También debemos considerar la posibilidad de que el proceso completo del desarrollo por clonación se pueda llevar a cabo fuera del cuerpo humano. Se han realizado algunos progresos asombrosos en el desarrollo de matrices artificiales. Probablemente será posible llegar desde un huevo construido especialmente hasta un niño normal, sin otra implicación humana más que la donación del huevo original y el núcleo y el mantenimiento del equipo ${ }^{31}$.

\section{Objeción $N^{\circ}$ 3: El período que va de la fecundación al día} decimoquinto sería de preparación y durante él se elaborarían los sistemas protectores y nutritivos, y sólo después se formaría el embrión. Este planteamiento ha sido hecho por la embrióloga Sra. Mc Laren, quien ha propuesto llamar preembrión al conjunto de estructuras anterior al día decimoquinto.

Para comprender cabalmente esta objeción es necesario tener presente los siguientes datos sobre el desarrollo embrionario: la mórula - estado del embrión que se produce a los tres o cuatro días de la fecundación, después de varias divisiones en células cada vez más pequeñas, y sin aumento de tamaño del conjunto- se divide en la masa celular interior, que constituye el embrioblasto, y una masa celular externa, que es el trofoblasto. Con la contribución tanto del trofoblasto como del embrioblasto se forman en el día quinto a sexto las membranas embrionales: el corion, que le garantiza al embrión la posibilidad de subsistencia, y el amnios, que le delimita el área de crecimiento. Del embrioblasto, que se transforma en el

\footnotetext{
${ }^{30}$ Serra, Angelo: “Per un' Analisi Integrata...”, 1993, pp. 93-97.

${ }^{31}$ Jenkins, John B.: Genética, 1986, pp. 742-743.
} 
disco embrional, se originará el cuerpo mismo del embrión. El disco embrional consta al principio de dos láminas o capas: el ectodermo y el endodermo. En el día decimocuarto o decimoquinto, en la parte caudal del disco, aparece la llamada línea primitiva o estría primitiva, de la cual parte la formación de la tercera lámina embrional, el mesoderma. De estas tres láminas o capas germinales proceden los tejidos y órganos del cuerpo humano. Con las tres capas germinativas, el embrión pasa a llamarse gástrula. La gastrulación comienza con la formación de la línea primitiva ${ }^{32}$.

Como puede verse por lo expuesto, primero se forman las membranas embrionales en los días quinto a sexto, y después se forma el disco trilaminar o gástrula, de donde se originarán los tejidos y órganos del embrión mismo, y esto es lo que da pie para que la Sra. Mc Laren sostenga que sólo con la gastrulación comienza el embrión, y antes hubo sólo un preembrión.

Sólo en el día decimoquinto después de la fecundación - dice ella_-, cuando ya se han establecido los sistemas de apoyo - protectores y nutritivos-, "puede comenzar a desarrollarse el embrión como entidad individual". Con la aparición de la estría primitiva - agrega - hay una entidad espacialmente definida llamada disco embrional, que 'puede' desarrollarse directamente en un feto y después en un niño" ${ }^{33}$.

A esta objeción cabe responder: 1) que el disco embrional con la estría primitiva es el resultado de un proceso unitario y teleológicamente ordenado que comienza con el cigoto, y llega sin solución de continuidad hasta la aparición de la estría primitiva ${ }^{34}$; 2) que no hay motivo para decidir que las estructuras de las membranas sean extraembrionales: Serra dice: "[...] las estructuras periféricas" — las que constituirán los sistemas protectores y nutritivos del nuevo ser - "y centrales" — que formarán el disco embrional- "constituyen conjuntamente, con su propia y específica estructura y destinación, el embrión, que se desarrolla como una unidad, la cual se continuará en ella y será reconocida más tarde como unidad fetoplacentaria"35, y 3) que, si no hubieran de considerarse las membranas

${ }^{32}$ Langman: Embriología Médica (Thomas W. Sadler, ed.), 1993, pp. 63-73; Villée: Biología, 1992, p. 528; Serra: "Per un' Analisi Integrata...", 1993, pp. 68-69.

${ }^{33}$ Mc. Laren, A.: "Prelud to Embryogenesis", 1986, pp. 5-23; citada por Angelo Serra en "Per un' Analisis Integrata...", 1993, p. 80.

En la misma posición, en substancia, está Gardner, biólogo de la reproducción, quien argumenta que antes de la gastrulación el desarrollo está claramente dirigido hacia la producción de diversos tipos de células especializadas que son esenciales para la vida del feto, "y sólo cuando ellas se diferencian, los tejidos que generarán finalmente el feto comienzan a organizarse y crecer". Gardner, R. C.: "Le Destin des Cellules dans l'Embryon", 1990, pp. 1476-1485, citado por Serra: "Per un’ Analisi Integrata...", 1993, p. 87.

${ }^{34}$ Serra: "Dalle Nuove Frontiere...", 1990, pp. 81-82.

${ }^{35}$ Serra: "Per un' Analisi Integrata...", 1993, p. 85. 
embrionales como partes del embrión - lo que no es así-, en todo caso habría que considerarlas como producidas por él.

15. Por lo anterior, el nombre de "preembrión" ha sido duramente criticado, Jérôme Lejeune lo tilda de "contorsión semántica" inventada hace poco por algunos colegas británicos ${ }^{36}$. El Profesor Axel Kahn, del Instituto Cochin de Genética Molecular de París, califica de absurda e interesada la denominación de "preembrión"37. En el mismo sentido se pronuncia el Profesor Jean Paul Rénard, director de Investigación de la Unidad de Biología del Desarrollo, INRA, en Francia ${ }^{38}$.

E. Davis, miembro de la Comisión Warnock, denuncia la introducción del término "preembrión como destinada a polarizar la discusión ética sobre la licitud de la investigación con embriones", en una carta a la revista Nature $^{39}$.

16. Objeción $N^{\circ}$ 4: Hasta el decimoquinto día el embrión no es individuo humano, porque antes de ese día pueden darse gemelos monocigóticos o quimeras.

Veamos primero lo tocante a los gemelos monocigóticos. El común de los gemelos provienen de huevos distintos, y se producen porque la mujer expulsa dos óvulos simultáneamente, son dicigóticos. Los gemelos

${ }^{36}$ Lejeune, Jérôme: ¿Qué Es el Embrión Humano?, 1993, pp. 21 y 43-44.

${ }^{37}$ Kahn, Axel: “Quelle Dignité pour l'Embryon Humanin?", 1996, pp. xiii-xiv, prefacio.

${ }^{38}$ Rénard, Jean Paul: "L'Embryon in Vitro", 1996, pp. 6-7.

${ }^{39}$ Serra, "Dalle Nuove Frontiere...”, 1990, pp. 82-83. El texto de la carta, que hemos compulsado de la mencionada revista, dice así:

"Señor:

Yo no puedo pretender haber leído cada palabra sometida a la Comisión Warnock de Investigación de la Fertilización Humana y Embriología, de la cual fui miembro, pero estoy razonablemente seguro de que al menos en nuestras discusiones la palabra 'preembrión' no fue jamás usada. Ciertamente sabíamos bien que el embrión humano por las primeras dos semanas de su existencia, y aún más, no tiene parecido visual, en cualquier cosa, a las posteriores etapas embrionales y fetales, Pero yo no puedo recordar empeños ni dentro ni fuera de la Comisión para redefinir las etapas tempranas como que no constituyesen un embrión. En el año pasado, sin embargo, la palabra 'preembrión' se ha estado introduciendo subrepticiamente. Por ejemplo, Maime Clarke (Nature, 319, 349; 1986) refiere que nueve consejos de investigación en Europa están de acuerdo en que la investigación debería ser restringida al 'preembrión', y que el Consejo Británico de Investigación Médica está apoyando investigación para desarrollar una prueba en orden a identificar los 'preembriones sanos'.

"Si la investigación con embriones fuera una materia no litigiosa, y si los científicos fueran generalmente de opinión de que la nueva terminología ayudaba a su comprensión, nadie tendría muchos escrúpulos en el cambio de nombre. Pero aquellos que están introduciendo 'preembrión' en el vocabulario saben perfectamente que la investigación es ciertamente litigiosa, y que los asuntos fundamentales están todavía por resolver. Ellos se quejan justificadamente cuando los embriones son descritos como 'niños no nacidos' en actas parlamentarias hostiles, pero están ellos mismos manipulando palabras para polarizar una discusión ética." (Nature, $\mathrm{N}^{\circ} 320,20-\mathrm{III}-1986$, p. 208.) 
monocigóticos provienen de un solo huevo. El embrión se divide en una etapa del desarrollo en que todavía se da la totipotencialidad: cada parte pasa a ser un embrión completo, y ambos tienen la misma información genética.

Si del cigoto, o del embrión de menos de quince días - se argumenta- pueden salir dos seres humanos, es porque no tiene aún ese embrión individualidad humana. Esta es la objeción más seria de las que se hacen a la tesis de que el ser humano comienza con la fecundación.

17. La mejor respuesta que hemos visto a esta objeción la formula el Profesor Serra en el penúltimo de sus trabajos sobre el tema del comienzo del individuo humano, esto es, en "Per un'Analisis Integrata dello 'Status' dell' Embrione Umano", y puede resumirse así:

i) La generación de gemelos monocigóticos es algo excepcional. El cigoto en el 99 al 99,6\% de los casos da origen a un solo individuo, lo que permite concluir que está en sí determinado a ello.

ii) El gemelismo monocigótico se debería a un "error genético" ambientalmente inducido. La causa de este fenómeno se conoce en forma deficiente. La explicación más antigua es que el gemelismo se produciría por la separación precocísima de blastómeras (células provenientes de las primeras divisiones del cigoto) dotadas de totipotencialidad, o por división posterior del embrión. Actualmente se abre camino la explicación de Boklage. Este autor, después de examinar un vastísimo número de casos, sienta conclusiones, ante todo, sobre el tiempo en que el fenómeno se produce. Para ello, clasifica los gemelos monocigóticos según compartan o no las membranas llamadas corion y amnios, en dicoriales -que tienen cada uno su corion-, monocoriales diamnióticos — que tienen en común el corion, pero cada uno su amnios- y monocoriales monoamnióticos - que son los que comparten ambas membranas. Se piensa que cuando los gemelos comparten una de estas membranas, ello se debe a que el grupo de células que ha originado el segundo embrión ha recibido este destino después de haber recibido el suyo las células que han originado la membrana compartida. Sobre esta base, se concluye que los grupos de células que originan los gemelos reciben su destino para un desarrollo separado alrededor del cuarto día en el caso de los gemelos dicoriales, que son el 31,2\%; entre el quinto y el sexto día en el caso de los gemelos monocoriales diamnióticos, que son el $65,4 \%$, y alrededor del séptimo día en el caso de los gemelos monocoriales monoamnióticos, que son el 3,4\%. Estos tiempos contrastan con el del comienzo de la división del cigoto: alrededor de treinta horas después de la fecundación, en que, según la 
explicación más antigua, puede empezar a producirse el fenómeno de la gemelación. Luego Boklage da su explicación sobre la causa del fenómeno, según la cual "un grupo de células, que define un esquema de simetría de un solo cuerpo en el 99,5\% de los embriones humanos vivientes, debe, de algún modo, formar dos de tales planos", debido a variación excesiva de algún factor, o a algún error en su colocación espacial, etc. Cualquiera que sea la explicación válida, se trataría de una aberración o error biológico.

iii) El cualquier caso, puede afirmarse que hay un primer embrión o sistema del cual se origina un segundo, y no cabe afirmar que el primer sistema ha pasado a ser o "devenido" el segundo, o que lo incluía. Ésta es la parte más fundamental del planteamiento del Profesor Serra: cualquiera que sea la causa del gemelismo monocigótico, su carácter excepcional demuestra que se trata de un error biológico que tiene lugar en el desarrollo precoz de un embrión humano, y que lo lleva a dar origen a otro embrión, y no de la generación de dos embriones a partir de un sistema matriz carente de individualidad en cuanto organismo humano. Un primer embrión, que no deja por ello de seguir su propio e individual desarrollo, origina un segundo embrión en un momento dado.

Esta explicación se confirma con el hecho bien conocido de que existen gemelos monocigóticos con genomas distintos, lo que indica que uno comienza después que el otro, originándose en él. Hay dos casos, dice Serra, citando un estudio de J. G. Rogers y otros ${ }^{40}$, en que un gemelo tiene trisomía 21 (causa del mongolismo), con 47 cromosomas, y el otro tiene cariotipo normal, con 46 cromosomas.

iv) La generación del segundo embrión sería un caso de reproducción asexuada. Se trata de una forma de reproducción análoga a la de los unicelulares, que generan por división celular, o a la reproducción por gemación, que se da, por ejemplo, en la hidra, o a la reproducción partenogenética: en todos estos casos es indiscutible la individualidad del organismo generador ${ }^{41}$.

18. Veamos ahora la objeción de falta de individualidad del embrión en cuanto se argumenta con la posibilidad de que se formen quimeras. Se llama "quimera" en Biología a un "individuo cuyo cuerpo posee poblaciones celulares derivadas de diferentes cigotos de la misma o de distinta especie". "Ocurre espontáneamente, como en gemelos, o producido artificialmente, como un organismo que se desarrolla a partir de porciones

\footnotetext{
${ }^{40}$ Rogers, J. G., L. Voullaire y H. Gold: "Monocigotic Twins Discordant for Trisomy" 21, 1982, pp. 143-146, citado por Serra, "Per un' Analisi Integrata...”, 1993, p. 93, nota 56.

${ }^{41}$ Serra, "Per un' Analisi Integrata...”, 1993, pp. 89-93.
} 
combinadas de diferentes embriones, o aquel en que se han introducido células o tejidos de otro organismo" 42 . Se produce la quimera por la fusión de embriones en división o de las masas celulares internas de dos o más blastocistos (embriones en el período de blástula).

C. R. Austin niega la individualidad del embrión temprano fundado en la posibilidad de que la división produzca gemelos monocigóticos, y también fundado en la posibilidad de que se formen quimeras ${ }^{43}$.

19. La respuesta a esta objeción es que la fusión de dos embriones puede significar el fin de la vida de uno, incorporándose su materia al otro, o acaso el fin de la vida de ambos para dar paso a la de un tercero, pero que no arguye en ningún caso falta de individualidad humana de los embriones que se fusionan, pues cada uno de ellos podría haber llegado a adulto, y en él habrían estado determinadas todas las características de ese adulto, según lo ya visto ${ }^{44}$.

20. Objeción $N^{\circ}$ 5: El genoma del embrión no está activado antes de la etapa de dos células, y probablemente no antes de la etapa de cuatro células: si el genoma no está expresado, incluidos los genes paternos, no hay individuo humano.

Como un niño no tiene hemofilia, si poseyendo genes de hemofilia, éstos no están expresados — dice el teólogo moralista Ford—, así no hay individuo humano, por más que haya genoma, si éste no esta activado ${ }^{45}$.

Esta objeción se funda en lo siguiente:

El ARNm (ácido ribonucleico mensajero) tiene por misión llevar la formación genética que está en el ADN del núcleo, al citoplasma, a los ribosomas, para la formación de las proteínas ${ }^{46}$.

42 Villée, Biología General, 1992, p. 846.

43 Austin, C. R.: “The Significance of Fertilization”, 1990, pp. 13-15, citado por Alejandro Serani en la obra Ética Clínica, de que es autor en conjunto con el doctor Manuel Lavados M., en el capítulo redactado por Serani, "El Comienzo de la Vida Humana", p. 220.

44 " [...] Nada obsta — dice el doctor Serani- para que, existiendo individualidad previa de ambos embriones, una de las individualidades persista y la otra se pierda. La muerte de los individuos no es novedad en el universo físico. La novedad estaría solamente en este caso, en que el proceso que conduce a ella sería excepcional o atípico". Serani, Alejandro: Ética Clínica, p. 221.

45 Ford, Norman M.: When did I Begin?, Conception of the Human Individual in History, Philosophy and Science, 1991, p. 118.

${ }^{46}$ La síntesis de las proteínas, determinada o regida por el ADN, se hace en el citoplasma, en los organoides celulares denominados ribosomas. En el citoplasma, por otra parte, se hallan dispersos los aminoácidos que, puestos en el orden correspondiente, han de constituir cada proteína. 
Ahora bien, es sabido que durante los primerísimos estadios del desarrollo se usan en cantidad ARNm y proteína derivados de genes de origen materno que se han acumulado durante el crecimiento y maduración el ovocito ${ }^{47}$.

La objeción consiste en que, si bien el embrión tiene, desde la fecundación, su propio genoma, éste no estaría activado, y siendo el genoma lo que dirige la actividad y desarrollo de todo sujeto o individuo biológico, no cabría reconocer en las primeras etapas del embrión un nuevo individuo humano.

A esta objeción cabe responder:

i) Estudios recentísimos han demostrado que al menos una parte del genoma del embrión se activa ya en la etapa de cigoto, pues se ha descubierto que el gen SRY del cromosoma "G" del genoma paterno, que es el primero entre los que controlan la diferenciación de las gónadas, se expresa en el estadio de cigoto pronucleado ${ }^{48}$. La activación de genes paternos - dice Serra - prueba la activación del genoma propio del cigoto, porque el padre no suministra — como sólo lo hace la madre - ARNm que permita el influjo en el embrión de genes paternos que no están en él, sino en el padre ${ }^{49}$.

ii) En todo caso, el ARN de origen materno forma parte del cigoto, y éste tiene en sí la facultad de ir activando su genoma.

Objeción $N^{\circ}$ 6: Las células del embrión precoz, hasta que se llega a la etapa de gástrula, son independientes entre sí, son cada una un individuo viviente aparte porque cada una puede dar origen a un ser humano completo y porque les falta formar una unidad: sus membranas solamente

El proceso mediante el cual el ADN, que está en el núcleo, dirige la síntesis de las proteínas, que tiene lugar fuera del núcleo, en el citoplasma, en los ribosomas, requiere que cuente con un "mensajero" que lleve la información genética del núcleo al citoplasma, precisamente a los ribosomas, y con un elemento recolector que busque los aminoácidos que están libres en el citoplasma y los lleve hasta los ribosomas, para que allí se ordenen de manera de formar la secuencia propia de la proteína que se trata de sintetizar.

$\mathrm{El}$ ácido ribonucleico se diferencia del $\mathrm{ADN}$ en que en vez de desoxirribosa tiene ribosa, y la base uracilo en reemplazo de la timina. Además tiene una cadena y no dos, como el ADN (Villée, op. cit., p. 601). Fuera del ácido ribonucleico mensajero y del de transferencia, existe el de ribosoma o ribosómico, que constituye en gran parte los organoides celulares del citoplasma que son los ribosomas, los cuales son el lugar de la síntesis de las proteínas (Villée, Biología General, 1992, pp. 601 y 847).

${ }^{47}$ Serra, Angelo y Roberto Colombo: "Identitá e Statuto dell' Embrione Umano: Il Contributo de la Bilogia", 1998, p. 139.

${ }^{48}$ Serra, Angelo y Roberto Colombo: "Identitá e Statuto dell' Embrione Umano: Il Contributo de la Bilogia", 1998, pp. 140-141; Serra, "El Estado Biológico del Embrión Humano. ¿Cuándo Comienza el Ser Humano?”, 1996, pp. 584-585.

${ }^{49}$ Serra, Angelo: “Per un' Analisi Integrata...”, 1993, p. 71. 
se tocan dentro de la zona pelúcida. Este planteamiento lo hace Norman Ford, teólogo austriano ${ }^{50}$.

En cuanto a la capacidad de las células de dar origen a un individuo completo, nos remitimos a lo dicho a propósito de los gemelos monocigóticos. Es útil, además, añadir que esa totipotencialidad de las células no significa indeterminación, sino la economía de la naturaleza para que de una sola célula pueda proceder la gran variedad de las que hay en el organismo, y para que puedan producirse las necesarias reparaciones, en su caso, y adaptaciones que puedan darse ${ }^{51}$.

Por otra parte, cada célula dotada de totipotencialidad, y que considerada con abstracción del programa de desarrollo del embrión, puede ser vista como posible origen de un individuo completo, debe considerarse como parte actual del embrión y cooperadora de ese programa de desarrollo, en el cual tiene un puesto y una función precisos ${ }^{52}$.

En cuanto a la supuesta separación física de las células cabe observar:

i) Que es incompatible con todo lo dicho sobre unidad y coordinación que el proceso de desarrollo muestra desde el primer momento, y

ii) Que desde la etapa de 2-8 células, éstas están en contacto entre sí y presentan una fuerte adhesión por medio de puentes citoplasmáticos; y están unidas por microvellos que se interconectan entre sí y además se adhieren a las membranas vecinas; y que en la etapa de 8-32 células, o de

${ }^{50}$ Ford, Norman M.: When Did I Begin? Conception of the Human Individual in History, Philosophy and Science, 1991, p. 137.

51 "Se debe, sin embargo, subrayar que esta capacidad no significa indeterminación respecto al término a alcanzar o pura posibilidad. Pedersen, embriólogo de clara fama, hace justamente observar que esta totipotencia de los blastómeros de los primeros estadios del desarrollo es una exigencia del nuevo organismo recién iniciado, ligada al alto grado de regulación de que necesita este proceso. Ella tiene, en efecto, un papel que él define como necesario en los eventos precoces de alocación celular, pues es evidente que las células progenitoras tienen descendientes tanto en la población de las células trofectodérmicas como en la de las células de la así llamada masa interna. Pero esto, afirma él, "sería imposible si faltase esta totipotencia". Así, es precisamente esta característica la que ofrece al embrión la posibilidad, dada la alta capacidad de regulación, particularmente en los primeros estadios del desarrollo, de aceptar modificaciones al programa e imponerlas a las células y tejidos que se están diferenciando en el interés del todo que se está formando" (Serra, Angelo: "Per un'Analisi Integrata...", 1993, p. 67).

52 "La totipotencialidad no significa indeterminación, sino [...] una capacidad actual de ejecutar un plan según un determinado programa. Cuando este plan es ejecutado según el programa, es decir, sin interferencias perturbadoras, la unidad morfofuncional en la totalidad fenotípica que se autoorganiza es el signo evidente de una existencia individual, y por ello de un individuo que, en este caso específico, se está construyendo a sí mismo; y cada célula, cualquiera pueda ser su potencialidad, está en su puesto correcto según el plan predispuesto y resulta involucrada en un proceso ordenado, único y coordinado" (Serra y Colombo: "Identitá e Statuto dell' Embrione Umano: Il Contributo de la Bilogia", 1998, 152). 
mórula, el contacto se intensifica, en la llamada compactación, sobreponiéndose las células unas a otras, y aplastándose para aumentar su área de contacto, y formándose como vías de comunicación intercelular, los desmosomas — que representan placas citoplasmáticas de las cuales parten microfilamentos internos-, y los complejos funcionales, que pueden ser uniones estrechas donde las membranas son cruzadas y atravesadas por microfilamentos, o uniones de agujero (gap junctions), en que las membranas están fundidas delimitando un canal. Estas vías de comunicación intercelular sirven para el tránsito de iones y pequeñas moléculas ${ }^{53}$.

"[E]l embrión en desarrollo — se lee en la Embriología Básica de Patten - puede considerarse como una comunidad celular cuya integridad y actividades dependen de un sistema bien desarrollado de comunicación intercelular [...]. En la actualidad se están tomando medidas para descubrir algunos de los medios por los cuales se comunican las células individuales entre sí. Se ha mostrado, por ejemplo, que en ciertas instancias pueden pasar corrientes eléctricas muy pequeñas, iones inorgánicos y hasta moléculas relativamente grandes a partir de una célula a otra. Este tipo de comunicación intercelular se lleva a cabo en regiones localizadas que se conocen como uniones con hendidura, en las que la membrana de una célula se encuentra en contacto íntimo con la de otra" ${ }^{54}$.

Objeción $\mathrm{N}^{\circ}$ 7: No puede haber individuo humano mientras no haya un suficiente desarrollo del sistema nervioso central, lo mismo que no hay ser humano después de la muerte cerebral.

Según este planteamiento, la vida humana se extendería desde el principio de la vida cerebral, que se daría en la octava semana de gestación, hasta la muerte cerebral.

$\mathrm{Si}$ se reconoce que el ser humano llega a su fin con la llamada muerte cerebral — se argumenta—, es decir, con la destrucción del cerebro, o del encéfalo completo, tronco y corteza, para seguir la opinión más exigente, es porque sin encéfalo no puede haber ser humano. Luego, el embrión que no ha llegado a tener cerebro capaz de funcionar, o encéfalo si se quiere, no es ser humano.

A esto cabe responder:

i) Que no está en absoluto claro que haya de identificarse el fin del individuo con el de su encéfalo o su cerebro. Hay médicos y biólogos que sostienen que las funciones de nutrición y crecimiento y demás que permanecen en el individuo con muerte encefálica, son funciones del organismo

\footnotetext{
${ }^{53}$ Serra: "Per un'Analisi Integrata...", 1993, pp. 65-66.

${ }^{54}$ Patten: Embriología Básica (Bruce M. Carlson ed.), 1990, p. 32.
} 
como un todo, y que la función a la que se debe la unidad del ser vivo no es la nerviosa sino la de nutrición.

ii) Que aunque se acepte la teoría de la muerte encefálica, no es lógico comparar al embrión que, iniciado su ciclo vital, está en una fase en que no necesita aún del sistema nervioso para la coordinación de sus funciones vitales, y tiene la capacidad de formar sus órganos definitivos, entre ellos el propio sistema nervioso, con el individuo que, al final de su vida, y con su organización definitiva, a la que corresponde y es necesario tener encéfalo y sistema nervioso, tiene su encéfalo destruido.

\section{ASPECTO FILOSÓFICO: \\ EL COMIENZO DE LA PERSONA HUMANA}

\section{II.a. Qué es la persona humana}

22. El concepto de persona es filosófico. La persona es, según la clásica definición de Boecio, "Substancia individual de naturaleza racional"55. La persona humana pertenece al mundo físico o corpóreo, y, dentro de él, al de los vivientes; tiene naturaleza racional —espiritual- y es, metafísicamente, un todo autónomo. Veamos los elementos de la citada definición.

\section{II.a.1. La substancia corpórea o física}

23. En los cuerpos físicos es el cambio un fenómeno constante. Hay un tipo de cambio, llamado accidental, en que el ser sigue siendo el mismo, aunque no lo mismo. Es el que se da, por ejemplo, cuando un animal crece o una fruta cambia de color por la madurez: algo hay que permanece, y que es lo básico, pues hace que el ser mantenga su identidad a través del cambio: es como un substrato en el que se dan las características accidentales: color, olor, tamaño, figura exterior, extensión, etc., que son las que cambian. A ese núcleo que no cambia y es soporte de los accidentes, se le llama substancia (de sub stare, estar debajo), porque sirve de fundamento a los accidentes, que no existen en sí mismos sino que son accesorios de la substancia.

Hay un segundo tipo de cambio, más profundo, llamado substancial, en que el ser mismo deja de ser lo que es para dar paso a otro ser corpóreo distinto. Por ejemplo, la combustión de un trozo de madera o la

${ }^{55}$ Boecio, De Duabus Aturis et una Persona Christi, c. III. 
muerte de un animal. En estos casos permanece algo amorfo, no perceptible por los sentidos, a lo que le es indiferente formar parte del ser que se corrompe o del que se genera, de la madera o de la ceniza. Aristóteles lo llamó materia ("hülé", en griego). Lo que cambia es, en tales hipótesis, lo que hace al ser ser lo que es, lo que lo determina, le da sus características. Aristóteles lo llamó forma ("morfé", en griego). La materia es potencia: capacidad de recibir perfección, y la forma, acto ("enérgueia" en griego): perfección o principio perfectivo. A esta explicación del cambio substancial, elaborada por Aristóteles, se la conoce como teoría hilemórfica.

La materia y la forma componen la substancia, y la substancia y los accidentes componen el ser corpóreo. A esta materia que es pura potencialidad se la suele llamar materia primera o prima, para distinguirla de la materia que ya tiene ser por su unión con la forma — por ejemplo madera o cobre-, y a esta forma se la suele llamar forma substancial, para distinguirla de las formas meramente accidentales, como, por ejemplo, el contorno o figura.

La estructura de materia y forma se revela también al considerar la existencia de pluralidad de individuos dentro de una especie: todos tienen idénticas perfecciones, naturaleza, modo de ser, pero cada uno es un ser aparte. Hay entonces en ellos un principio determinante, que los hace converger, la forma, y uno determinable, pasivo, amorfo, la materia, que hace que cada cual sea un ser aparte; que permite que la misma forma o estructura básica se vaya repitiendo en distintos individuos, por lo cual se dice de la materia que es principio de multiplicación y de individuación.

\section{II.a.2. Los vivientes}

24. Entre los seres corporales están los vivientes: vegetales, animales y seres humanos. No podemos propiamente definir la vida, pero sí caracterizarla por un cierto ser para sí, una cierta autodestinación, que admite grados, una cierta capacidad de movimiento inmanente, que empieza en el viviente y termina en él, una capacidad de operar en beneficio propio en virtud de un principio intrínseco, nutriéndose, creciendo y reproduciéndose los vegetales; conociendo además, mediante los sentidos, la materialidad de las cosas, apeteciéndolas mediante los apetitos sensibles y pudiendo moverse hacia ellas por la facultad locomotriz, los animales; y conociendo, además, la naturaleza de las cosas abstraídas de su materialidad y en definitiva el ser de las cosas, mediante la inteligencia, y apeteciendo ese ser como bien mediante la voluntad, los seres humanos.

Hay vida vegetativa, sensitiva y racional. 


\section{II.a.3. El alma}

25. La vida, como todas sus perfecciones, la deben los seres corpóreos vivientes a su forma. La forma de los vivientes se llama alma (del latín anima), porque los anima o hace no ser inertes, sino moverse a sí mismos y operar. Hay alma vegetal, alma animal o sensible y alma racional, intelectual o humana.

El concepto de alma no es un concepto religioso o propio de la Revelación divina, como cree por ignorancia mucha gente, incluso la de cierta cultura, sino un concepto filosófico. Platón dedicó al alma su célebre diálogo El Fedón —destinado a demostrar la inmortalidad del alma humana-, y Aristóteles cuenta entre sus principales obras el tratado Del Alma.

Aristóteles definió el alma como "el acto primero de un cuerpo natural orgánico" 56 . El alma es, pues, la forma substancial de los vivientes.

26. El hombre, a diferencia de los animales, que sólo conocen lo sensible de las cosas, lo concreto, lo individual, puede conocer la estructura fundamental común a todos los individuos de una especie, o a todas las especies de un género, con prescindencia de la individualidad. La representación sensible, individual es la imagen; la que recoge la forma común a toda la especie separándola o abstrayéndola de la individualidad, es la idea. La idea de caballo, por ejemplo, cuadra a todos los individuos de la especie, al margen de las peculiaridades que los distinguen y de lo que los hace a cada uno ser un ser aparte, un individuo; es decir, con prescindencia de la materia o materia primera que es el principio de individuación. Eso significa que la mente humana puede actuar con independencia de la materia; y si puede actuar con independencia de la materia es porque su ser es independiente de la materia. Una forma que tiene ser, con independencia de la materia, es lo que en filosofía se llama espíritu. Por eso decimos que el alma humana es espíritu, o que es espiritual ${ }^{57}$.

En el hombre no puede haber sino un alma, porque ella es forma substancial, y si hubiera más de una forma substancial habría varios seres. Por tanto el alma espiritual del hombre causa su vida vegetativa, su vida animal o sensitiva, y su vida específicamente humana.

El alma humana tiene ser o entidad, es substancia, por sí sola, pero se une a la materia del hombre como forma substancial para constituir a la

${ }^{56}$ Del Alma, Libro II, c. I, 412, a-b.

${ }^{57}$ Aristóteles decía que el intelecto viene de afuera y es de origen divino, "pues no tiene nada de común una actividad corporal con la actividad propia de él" (Generación de los Animales, L. II, c.3, 736 a 27- b. 28). 
persona humana; no son dos seres distintos que se unen, sino una forma que es ser y substancia y un coelemento - la materia prima- que por sí solo no es ser, sino un co-principio potencial o limitativo, y cuantificador. No hay, pues, dos substancias sino una sola: un alma encarnada.

Siendo espiritual, o pura forma substancial, el alma humana es simple, no consta a su vez de materia y forma, por lo que no puede corromperse: no está sujeta a cambio substancial que consiste en separación de materia y forma. Es en consecuencia inmortal.

Por otra parte, y yendo al origen del alma de cada ser humano, como ella es substancia aparte de la materia, y como la materia es principio limitativo o potencial, y causa, por tanto, la cantidad o composición de partes extensas unas fuera de otras, que es una suerte de límite, el alma humana en sí misma no consta de partes, antes es principio de unidad. De ello se sigue que no puede dividirse. Por consiguiente, el alma humana no puede emanar de la de los padres.

Tampoco puede surgir de la potencialidad de la materia - los gametos actuando el uno sobre el otro-, como en los animales, porque no es material. Luego, no queda sino que sea creada por Dios, o de origen divino, como dice Aristóteles en La Generación de los Animales ${ }^{58}$.

\section{II.a.4. Naturaleza racional: inteligencia, posesión de los seres y} autoposesión por el conocimiento, subjetividad

27. Mediante el conocimiento intelectual el hombre posee la forma de las cosas, sabe lo que son, y no sólo cómo son sensiblemente, y sabe, entonces, que son, conoce el ser de las cosas, que como objeto de conocimiento se llama verdad, y lo apetece con su apetito racional o voluntad, bajo el nombre de bien.

Conociendo el ser de las cosas limitadas y dependientes, puede llegar al conocimiento del ser infinito e independiente que la existencia de aquéllas supone - porque no explica la existencia de las cosas limitadas, contingentes y que comienzan, una cadena o serie infinita de causas todas dependientes-, es decir, puede venir al conocimiento y amor de Dios.

Por otra parte el hombre por su inteligencia puede conocerse y amarse a sí mismo como ser y bien, y por tanto poseerse a sí mismo, y orientar los actos de su voluntad desde sí mismo, es decir, ser libre o dueño de sus actos.

\footnotetext{
58 Véase nota anterior.
} 
Tiene entonces el hombre una interioridad, una intimidad, una subjetividad que lo hace ser un ser para sí, un fin y no un medio, y que lo convierte en sujeto, separándolo radicalmente de las simples cosas u objetos.

\section{II.a.5. La personalidad}

28. Visto todo lo anterior, podemos decir que el hombre es persona porque es substancia, es decir, existe en sí y no en otro, como los accidentes o accesorios, ni con otro, como la materia o la forma; porque es substancia individual, porque no es una abstracción como la idea de la especie, por ejemplo la humanidad; y porque es de naturaleza racional, ya que su forma substancial o principio de vida y de ser es espiritual, capaz de conocimiento intelectual, de conocer el ser de los otros seres y de sí mismo, y de así poseerlos y autoposeerse en su ser, y en sus actos, obrando desde sí, es decir, con libertad; por todo lo cual el hombre es un fin en sí, un sujeto, que es de sí mismo y no de otro, a diferencia de las cosas u objetos, lo que le confiere su dignidad ontológica superior.

\section{II.b. Cuándo el embrión es persona humana}

29. De todo lo dicho, resulta que no hay ser humano ni persona humana sin forma substancial humana, es decir, sin alma humana. El problema de saber en qué momento comienza la persona humana se reduce, pues, a saber cuándo el embrión tiene alma humana.

Con los conocimientos biológicos actuales que nos certifican que el sujeto biológico hombre comienza con la concepción, como vimos en la primera parte de este estudio, la respuesta no puede ser sino que la persona humana comienza ya también con la concepción, porque individuo biológico humano y persona humana son, como es obvio, una misma realidad mirada en dos niveles y campos de conocimiento distintos, la biología y la filosofía; y porque si los seres son por su forma substancial, no puede existir un sujeto biológico hombre sin la forma substancial humana.

Esta respuesta que ahora parece tan clara, no lo ha sido antes, y como las doctrinas antiguas tratan de sobrevivir, conviene conocerlas, para dilucidar adecuadamente el problema en estudio. 
II.b.1. Requisitos que debe tener el cuerpo para que pueda concluirse que tiene alma humana

Ante todo hemos de recordar que, como enseña Aristóteles, el alma es el acto primero de un cuerpo natural organizado (Acerca del Alma, 412 $a-b)$.

Santo Tomás, glosando esta definición, nos dice: "se llama cuerpo orgánico el que tiene una diversidad de órganos. La diversidad de órganos es necesaria en el cuerpo que sustenta la vida en razón de las diversas operaciones del alma. En verdad, el alma, como es la forma más perfecta entre las formas de las cosas corporales, es principio de diversas operaciones, y por eso requiere la diversidad de órganos en su perfectible" (el cuerpo o entidad a la cual perfecciona) (Comentarios al Tratado Del Alma, $\mathrm{N}^{\circ}$ 230, L. 2, c.1, lección 1).

El alma es, pues, el acto primero de un cuerpo natural organizado: un organismo es una unidad natural de partes cualitativamente y no sólo cuantitativamente diversas; la diversidad de partes, opuesta a la uniformidad y a la homogeneidad, es lo que hace posible el movimiento en los seres vivientes corpóreos, el cual supone parte movida y parte motora (como nada se mueve a sí mismo, tiene que haber parte movida y parte que la mueva en el movimiento de los vivientes corpóreos), es decir, diversidad de partes funcionalmente distintas. Las operaciones son movimientos, y a través de ellas se desenvuelve la vida en los seres finitos.

Un primer requisito para que el cuerpo pueda estar informado por el alma humana es que haya en él una organización: que tenga diversidad de órganos para la variedad de funciones de la vida.

De este requisito surge la necesidad de un segundo, y es que la organización del cuerpo sea específicamente humana, es decir, la propia de la especie humana; pues evidentemente los órganos del cuerpo han de ser los que se ordenan a las operaciones propias del hombre.

Por último, para decidir que hay alma humana es necesario un tercer requisito: que el cuerpo esté de tal modo revestido de características individuales humanas, que pueda referirse a un alma individual concreta, creada para ese cuerpo y, por tanto, distinta de las demás de la especie humana. Ello porque "como el alma se une al cuerpo como forma - dice Santo Tomás-, no se une sino al cuerpo del cual es acto" (Suma Contra Gentiles, L. II, c. 89) ${ }^{59}$.

${ }^{59}$ Emilio Navarro Rubio señala y examina los tres requisitos, y dice, explicando el último: "se necesita, además, que la organización material esté conmensurada al alma racional; es decir, que haga relación a un alma propia y concreta". "Ahora bien — dice Santo Tomás—, 


\section{II.b.2. Animación inmediata y animación retardada}

30. El concebido o nascituro puede tener alma humana, y por consiguiente ser persona humana, desde el primer momento de su existencia: animación inmediata, o desde algún momento posterior: animación retardada. Son las únicas dos respuestas posibles a la cuestión que nos ocupa.

La tesis de la animación inmediata presenta las siguientes dificultades: $1^{\circ}$ ) al principio faltan al embrión los órganos necesarios para realizar el conocimiento sensible que forma las imágenes de las cosas, a partir de las cuales se forman las ideas, por abstracción que hace la inteligencia espiritual, y tiene lugar el conocimiento intelectual, que es lo que caracteriza a la persona humana; $2^{\circ}$ ) habría que admitir que toda la mutación que va desde el huevo o cigoto al feto que ya tiene los órganos definitivos del hombre, cerebro y sistema nervioso, órganos de la sensibilidad, corazón, etc., es un cambio o mutación meramente accidental, pues si fuera substancial supondría una sucesión de diversas formas substanciales, de las cuales la última vendría a ser el alma humana, que entonces no habría informado al embrión desde el momento mismo de la concepción, y $3^{\circ}$ ) habría que añadir a la lista aristotélica de las facultades o potencias de la vida vegetativa que producen su efecto sobre el viviente que las posee, que son las de nutrición y crecimiento, una potencia o facultad orgánico-formativa o morfogenética, o de desarrollo cualitativo, encargada de llevar al embrión desde una organización elemental y provisoria, a la organización definitiva, propia de las operaciones específicas del ser humano; es decir, habría que admitir en el ser humano la existencia de una primera etapa en que le fuera imposible — por falta de los órganos correspondientes - realizar las operaciones específicamente humanas, o, si se prefiere, en que no hubiese en él otra operación humana que la formación de sus órganos definitivos.

Los mismos problemas se presentan, por lo demás, analógicamente, para los animales y los vegetales.

Pero la tesis de la animación retardada ofrece un problema mayor, por cuanto parece excluir el concepto mismo de la generación biológica, desde que los padres — humanos, animales o vegetales — no engendrarían

la forma y la materia deben estar siempre proporcionadas entre sí y como naturalmente adaptadas, porque el acto propio en su propia materia tiene lugar [...] porque esta alma está adaptada a este cuerpo, y la otra a aquél, y aquélla al otro, y así todas las demás" (Suma Contra Gentiles, L. II, c.81). Santo Tomás dice claramente que cada cuerpo posee un alma a su medida, "commensurata secundum mensuram corporis". Así como cada organismo en particular se caracteriza por ciertas notas individuales que le son propias, así también cada alma tiene notas individuales características que corresponden a las del organismo con que está unida" (Navarro Rubio, Emilio: El Momento de la Unión del Alma con el Cuerpo, 1957, pp. 98-99). 
un semejante, sino un ser inferior que a posteriori, y no por obra de los genitores, adquiriría la naturaleza paterna.

Ofrecemos a continuación una visión esquemática de las principales soluciones que se han propuesto a lo largo de la historia, y que son: $1^{\mathrm{a}}$ ) la aristotélico-tomista de la virtud formativa paterna, en que un embrión sin órgano alguno va siendo modelado por una virtud formativa de procedencia paterna, que lo convierte primero en vegetal, después en animal con animalidad común, y luego en tal animal o en hombre; $2^{\mathrm{a}}$ ) la preformista, surgida entre los biólogos del Renacimiento, según la cual el hombre -y lo mismo mutatis mutandis el animal o la planta- está en miniatura completamente formado ya en el óvulo o en el espermio o en el huevo fecundado, y sólo le falta crecimiento, y $3^{\mathrm{a}}$ ) la de la facultad formativa intrínseca $\mathrm{o}$ construcción por el embrión que es humano desde el principio, de sus órganos definitivos.

\section{II.b.3. La teoría aristotélico-tomista de la virtud formativa paterna}

31. Aristóteles, médico y biólogo a la par que filósofo, desconoció la biología celular, no tuvo microscopio, y pensó que el embrión era sangre coagulada de la menstruación y semen paterno, y que carecía de organicidad, esto es, de partes cualitativamente distintas, requisito indispensable para el movimiento y la operación, y por tanto para la vida, que es capacidad de automoción natural ${ }^{60}$.

Si el embrión no tenía órganos ni por tanto vida, ni alma, ¿cómo las adquiría? Tenía que ser por un agente exterior que lo fuera transformando: éste era el espíritu -en el sentido de substancia gaseosa y no en el de espiritualidad - presente en el semen paterno, un gas de naturaleza análoga a la del elemento astral ${ }^{61}$. Este espíritu imprimía al elemento femenino un movimiento recibido del generador masculino, que producía la progresiva diferenciación de las partes, disponiéndolo a recibir, cuando estuviesen los órganos correspondientes, el alma vegetal primero, luego una sensitiva o animal común a todo animal, y luego la del animal específico de que se tratase o del hombre, al cual el intelecto le venía de afuera por ser divino ${ }^{62}$.

La facultad o potencia residente en este espíritu configurador sería llamada posteriormente por Galeno "virtud formativa" 63 .

${ }^{60}$ Generación de los Animales, L. II, c. 4, 740 b; 741 b-742 a; "Historia de los Animales", L. VII, 596 c).

${ }^{61}$ Generación de los Animales, L. II, c.3, 736 b-737 a.

${ }^{62}$ Generación de los Animales, L. II, 734 b; 736, a 27- b 28.

${ }^{63}$ Galeno, Claudio: De Naturalibus Facultatibus, L. I. C.6, citado por Barbado, Manuel: ¿Cuándo se Une el Alma al Cuerpo?, 1943, pp. 53-54. 
32. Para Aristóteles el concepto de generación se salvaba con la procedencia paterna de la virtud formativa. La acción de ésta producía, en un momento dado, un órgano que servía de principio a los otros, el corazón en el hombre ${ }^{64}$.

Según Aristóteles, el feto de varón alcanzaba la forma humana alrededor de los cuarenta días y el femenino alrededor de los noventa ${ }^{65}$.

33. Con esta explicación aristotélica se quería salvar el principio de la proporción que debe haber entre cada cuerpo y su forma substancial, pues cada alma de las que se sucedían en el embrión se daba al estar ya presentes los órganos a ella correspondientes, vegetativos, animales, humanos.

Esta explicación recibió una contundente crítica del filósofo y Padre de la Iglesia Oriental, San Máximo Confesor (nacido en Constantinopla hacia el año 580 y muerto en 662): el hombre resultaba, según ella, engendrando una planta o un animal, y no un semejante ${ }^{66}$.

Santo Tomás de Aquino y la generalidad de los autores de los siglos XIII a XVIII siguieron a Aristóteles.

"Tampoco puede decirse - expresa Santo Tomás- que el alma está desde un principio en el semen (semilla, embrión) según su esencia completa, aunque sus operaciones no aparezcan por defecto de los órganos. Porque como el alma se une al cuerpo como forma, no se une sino al cuerpo del cual es acto. Pues el alma es el acto del cuerpo orgánico. Luego, antes de estar organizado el cuerpo, el alma no está en el semen actualmente, sino sólo en potencia o virtualmente" ${ }^{\text {67. }}$.

Para Santo Tomás, la potencia formativa obra en dependencia del alma del padre, y sólo por ello se dice que es potencia del alma ${ }^{68}$, pero es intrínseca al embrión, afirmación esta última incompatible con la anterior,

${ }^{64}$ Generación de los Animales, L. II, 734 b-735 a.

${ }^{65}$ Historia de los Animales, L. VII, 583 b.

66 “. [...] Y si afirmáis que aquello tiene la sola alma nutritiva y de crecimiento, aquel cuerpo que se nutre y aumenta será ciertamente, por esta razón según vosotros, de alguna planta, no de hombre, y entender cómo el hombre sea padre de una planta, me vuelvo hacia cualquier consideración, y ciertamente no lo logro, como no tenga en verdad del hombre la existencia según la naturaleza. Si por el contrario afirmáis que en el embrión se encuentra la sola alma sensitiva, el hecho de tener el embrión desde la concepción alma ciertamente de caballo, o de buey o de algún otro de los animales terrestres o volátiles, quedará de manifiesto, y, por vosotros, según la naturaleza el hombre no será padre del hombre, en primera concatenación, sino de alguna planta, como decía, o de alguno de los animales terrestres. ¿Y qué sería más absurdo y demencial que esto?" (San Máximo Confesor: Ambiguorum Liber, Patrología Griega, XCI, p. 1338)

${ }^{67}$ Santo Tomás de Aquino: Suma Contra Gentiles, L. II, c. 89.

${ }^{68}$ Santo Tomás de Aquino: Suma Contra Gentiles, L. II, c. 89, y De Potentia, q. 3, art. 9 , ad 11. 
y que hace Santo Tomás para responder a la dificultad de que siendo la virtud formativa potencia del alma paterna, se suspendería la formación del embrión si el padre saliera de viaje ${ }^{69}$. Para Santo Tomás la virtud formativa conserva el influjo del alma del padre como el proyectil el influjo del que lo lanza.

La especie del concebido va cambiando, pues se da - dice Santo Tomás - una sucesión de formas substanciales interinas o transitorias - de semen, de sangre, vegetativa, animal- que van preparando el advenimiento de la forma definitiva. Los seres intermedios no tienen la especie perfecta, sino que están como en camino a la especie ${ }^{70}$. No cabe entonces objetar a esta opinión, dice Santo Tomás, que según ella el hombre provendría de un animal de distinta especie ${ }^{71}$.

35. Esta doctrina de Santo Tomás - a la que ahora algunos se aferran anacrónicamente y sin suficiente profundidad filosófica- resulta del todo inadmisible a la luz de la propia metafísica tomista.

En efecto, en primer lugar, no cabe poner una potencia del alma, cual es la formativa, como intrínseca a un embrión al que no se reconoce al principio vida ni alma, porque lo accesorio sigue la suerte de lo principal; en segundo lugar, es absurdo poner una potencia del alma del padre en comisión de servicio en el embrión e intrínseca a éste, porque las potencias del padre no pueden residir sino en el alma de éste; en tercer lugar, es absurdo poner en un ente una potencia ordenada a su corrupción, siquiera sea para preparar la adquisición de una forma superior, porque todo accidente se ordena al bien del sujeto en que reside; en cuarto lugar no cabe suponer, para soslayar la objeción de que el hombre provendría de un animal, seres intermedios sin especie perfecta en el curso del desarrollo embrionario, porque todo ser corpóreo tiene que pertenecer a alguna especie, por muy transitorio que pueda ser, desde que tiene $-\mathrm{y}$ no puede menos de tener-materia prima y forma substancial.

La teoría de la virtud formativa no hace más que trasladar o diferir el problema que trata de solucionar, pues esa virtud no puede dar al embrión la organicidad que en él se echa de menos, desde que ella misma no la tiene ni la puede tener, al ser accesoria de un ente que carece de tal organicidad: el propio embrión. Santo Tomás sostiene que la virtud formativa es como cierta moción o impulso del alma del generante, y no alma ni

\footnotetext{
${ }^{69}$ Santo Tomás de Aquino: De Anima, q. 16, art. 11, ad 2.

${ }^{70}$ Santo Tomás de Aquino: De Potentia, q. 3 art. 9, ad 9; Santo Tomás de Aquino: Suma Contra Gentiles, L. II, c.89.

${ }^{71}$ Santo Tomás de Aquino: De Potentia, q. 3, art. 9, ad 10.
} 
parte de alma, por lo que no es necesario que tenga órgano alguno en acto; o sea, la refiere implícitamente a la organicidad del padre; pero ello es contradictorio con afirmar que es intrínseca al embrión ${ }^{72}$.

Santo Tomás, al igual que Aristóteles, se enfrentó al problema de conciliar el hecho innegable de la generación, consistente en que los padres produzcan un semejante, con el principio de la debida proporción entre el alma y el cuerpo al que ella informa: creyendo homogéneo, carente de partes diferenciadas, al huevo o cigoto, no podía Santo Tomás admitir que estuviese informado por un alma humana, la que sólo puede hallarse en un cuerpo con organicidad humana. Es más, ni siquiera podía admitir que tuviese vida. Tampoco podía admitir que hubiese una facultad morfogenética intrínseca en un cuerpo inorgánico y sin vida: ¿Cuáles habrían sido los órganos generadores de la organización definitiva? Y lo que es más importante, no podía concebir una autoformación del cuerpo sin jamás haberla visto, ni menos podía concebirla como operación humana en cuanto destinada a desarrollar el cuerpo humano, y declarar, en consecuencia, que en el embrión hay alma humana porque hay en él una operación humana. Por otra parte, si el nuevo ser humano no recibe de sus padres los principios corpóreos, no hay generación, y desaparece el concepto mismo de paternidad; y decimos "los principios corpóreos", porque el alma, la forma substancial, es puesta por Dios para cada hombre: los padres ponen, y han de poner, para que exista generación, la materia apta para recibir el alma.

Como puede apreciarse, el problema tenía un dato que hoy ha cambiado, en virtud de los nuevos conocimientos biológicos: el huevo o cigoto no es homogéneo: consta en realidad de partes, tiene una complejísima organicidad, esta organicidad sólo es propia del embrión humano, y contiene una potencia activa o facultad morfogenética que produce todo lo que el individuo ha de ser biológicamente cuando adulto.

Santo Tomás, al igual que Aristóteles, intentó solucionar el problema recurriendo a la vis formativa o virtud formativa dependiente del alma del padre, entidad cuya existencia dedujo del hecho de que sin ella el problema parecía insoluble: estaba en un callejón sin salida.

\section{II.b.4. El preformismo}

36. Con el invento del microscopio y el descubrimiento del óvulo por Garff en 1672 y del espermatozoide por Hamm y Leeuwenhoek en 1697, apareció la doctrina llamada "preformismo". Según ella, en el esper-

${ }^{72}$ Santo Tomás de Aquino: Suma Teológica, I, q. 118, a. 1, ad 3. 
matozoide, o en el óvulo, o en el huevo fecundado - hay todas estas variantes- está perfectamente formado el hijo, siendo su desarrollo asunto sólo de crecimiento.

El Padre Manuel Barbado, psicólogo español de este siglo, dice al respecto:

El ilustre médico italiano Marcelo Malpighi apoyó la tesis preformista, asegurando que, según su experiencia, por muy pronto que se observe el huevo fecundado de gallina, siempre se encuentra en él un pollito ya organizado; pero el apoyo principal vino de los naturalistas que empezaban a utilizar el microscopio en el estudio de los elementos germinales masculinos. Antonio Leeuwenhoek, el descubridor de los espermatozoos, y pocos años más tarde (1699), Francisco de Plantade (Delempatius) dibujó "homúnculos" (hombrecillos) encapuchados, que decía haber copiado del natural. Leeuwenhoek reprodujo las figuras, dándolas como fiel representación de la realidad. O. Jacobeus (1676) decía que había observado una ranita microscópica en el óvulo de rana no fecundado. Gautier d'Agosty afirmaba muy en serio que, observando al microscopio semen de animales, había visto gallitos, caballitos y burritos con grandes orejas ${ }^{73}$.

De los preformistas, algunos sostuvieron que el alma de los "homúnculos" que pensaban haber hallado en las células generativas había sido infundida a cada cual al principio del mundo. Los que así discurrían se dividían en "ovulistas" y "espermatistas", según creyesen hallarse los homúnculos en los óvulos o en los espermatozoides. Otros preformistas sostuvieron que el alma era infundida al momento de la generación ${ }^{74}$.

Huelga decir que el preformismo fue abandonado cuando se alcanzaron los conocimientos científicos modernos más fundamentales sobre la reproducción, con el estudio de la constitución molecular de las células de la reproducción (Kölliker, mediados del siglo pasado), y con el descubrimiento del modo como se opera la reproducción (Oscar Hertwig, 1875) ${ }^{75}$.

\section{II.b.5. La doctrina de la facultad formativa intrínseca al embrión}

37. Esta doctrina es sin duda la que se impone desde que sabemos que el embrión a partir de la concepción es orgánico o dotado de partes cualitativa y funcionalmente distintas; que es el mismo sujeto biológico

${ }^{73}$ Barbado, Manuel: “¿Cuándo Se Une el Alma al Cuerpo?”, 1943, p. 22.

${ }^{74}$ Navarro Rubio, Emilio: El Momento de la Unión del Alma con el Cuerpo, 1957, p. 29 y 30 .

${ }^{75}$ Navarro Rubio, El Momento de la Unión del Alma con el Cuerpo, 1957, p. 30. 
desde la etapa de cigoto hasta la muerte; que tiene ya dentro de la especie humana la individualidad biológica por obra del genoma, y que en su organicidad básica o elemental existe una facultad morfogenética u orgánico-formativa cuya base está en el genoma, la cual tiene por tarea la formación de una organicidad humana definitiva; de los órganos que tendrá el adulto. En esta doctrina, los gametos son causa eficiente de la disposición a recibir el alma racional, al originar la organicidad básica, y el alma racional es causa eficiente de la transformación de la organicidad básica en definitiva, que es un cambio accidental, porque la forma substancial es siempre causa eficiente de los cambios accidentales.

Esta doctrina fue anticipada con más o menos claridad por diversos autores a lo largo de la historia. Podemos citar ahora, entre otros, a los siguientes: 198-211) ${ }^{76}$.

i) Alejandro de Afrodisias, filósofo que enseñó en Atenas (hacia

ii) Temistio de Paflagonia (h. 320-390), retórico que enseñó en Roma y Constantinopla, del cual se conservan sus comentarios al Tratado Del Alma de Aristóteles, quien expresa:

El alma "fabrica y construye un instrumento conveniente y acomodado a ella: se traza y prepara ella un domicilio, y no entra en él luego de formado y preparado. No del mismo modo que la cítara es elaborada y antes construida, y luego usada para la música, es así también el cuerpo dispuesto y antes construido, y después ofrecido al alma para que lo tome" 77 .

ii) San Máximo Confesor, cuya doctrina se ha expuesto, con cita textual, más arriba ${ }^{78}$.

iv) Siger de Bravante, el famoso contemporáneo de Santo Tomás de Aquino (1235-1284), y el más influyente representante del averroísmo latino, quien después de haber aceptado que cada hombre tiene un alma propia, lo que antes negaba, dice sobre nuestro tema:

[...] no hay primero un alma vegetativa que una sensitiva, y primero una sensitiva que una intelectiva, porque, si se genera un compuesto

${ }^{76}$ Lib. I. q. natur, c.25, citado por Zacchia, Paulo: Quaestiones Medico-Legales, T. II, Venecia, 1751, L. IX, tít. I, p. 208, $\mathrm{N}^{\circ} 126$.

77 Anima "fabricatur, architectaturque convenniens sibi accommodatumque instrumentum; deformat ipsa sibi et praeparat domicilium, non deformatum autem et praeparatum demum subit. Non idem quemadmodum cythara dedolatur prius et conditur, tum demum adhibetur ad musicam, ita et corpus ornatur ante instruiturque, mox animae sumedum offetur" (De Anima, 1. I, c. 22, Venecia 1502, folio 74, citado por Barbado, Manuel: “¿Cuándo Se Une el Alma al Cuerpo?", 1943, p. 47).

${ }^{78}$ Véase Ambiguorum Liber, Patrología Griega, XCI, p. 1338, № 33. 
por una generación, y una generación se termina en una única forma, es manifiesto que se tendrá una única forma. Esta forma, sin embargo, tiene partes y potencias diversas: primero en el embrión aparecen las operaciones vegetativas, porque sus potencias están más cercanas a la generación [...]"79.

Como se asuma que al alma en el cuerpo animado preexiste otro acto, digo que es falso, porque ni preexiste cuerpo en acto, ni substancia en acto, ni cuerpo orgánico: antes al contrario, todas estas cosas tienen su razón de ser por el alma y son causadas por el alma: [...] la organización del cuerpo proviene del alma ${ }^{80}$.

v) San Gregorio Niseno (335-394 D.C.), Padre de la Iglesia Oriental, quien dice: “[...] Pues como en eso que en el útero materno se deposita para la concepción del cuerpo, antes que se forme, no puede verse una distinción articulada de miembros coherentes, así tampoco la virtud propia del alma puede en eso mismo conocerse antes que ella progrese en orden a sus disposiciones. Y así como para nadie ofrece dudas que aquello mismo se conforma con diversos miembros y diversas vísceras, sin que ninguna facultad externa intervenga para llevarlo a cabo: sino una facultad que le ha sido impresa por la naturaleza, siendo esto de la incumbencia de su obra e inclinación: por la misma razón, para nosotros, se debe pensar del alma que está presente, aunque en la parte externa y aparente del hombre, no proporcione ningún indicio de sí por algunas afecciones" $"$.

vi) Tomás Fyens, médico y filósofo de Lovaina, quien publicó en Amberes, en 1620, el libro De formatione foetus liber, in quo ostenditur animam rationalem infundi tertia die: Libro de la formación del feto en el cual se demuestra que el alma racional se infunde en el tercer día. Este autor sostiene que el alma racional se infunde al cuerpo una vez que se han mezclado las semillas de ambos padres, y que por el calor del útero ha

79 “[... Non est prius anima vegetativa quam sensitiva, et prius sensitiva quam intellectiva, quia, si generatur compositum una generatione, et una generatio terminatur ad formam unam, patet quod habebit formam unam. Ista tamen forma habet partes et virtutes diversas: prius in embryone apparent operationes vegetativae, quia virtutes eius sunt propinquiores generationi [...]". (De Brabante, Siger: "Quaestiones in Libros Aristotelis de Anima”, II, 7, en la edición de F. Van Steenbergen, Siger de Brabant d'Après ses Oeuvres Inédites, en colección Les Philosophes Belges, XII, Lovaina, 1931, p. 67, citado por Lanza, A.: "La Questione del Momento in cui l'Anima Razionale e Infusa nel Corpo", 1938, p. 349.)

80 "Cum assumitur quod animae in corpore animato praeexistit alius actus, dico quod falsum est, quia nec praeexistit corpus in actu, nec substantia in actu, nec corpus organicum: immo ista omnia rationem habent ex anima et causantur per animam... Organizatio corporis est ab anima" (De Brabante, Siger: "Quaestiones in Libros Aristotelis de Anima", II, 3, en la edición de F. Van Steenbergen, Siger de Brabant d'Après ses Oeuvres Inédites, en colección Les Philosophes Belges, XII, Lovaina, 1931, p. 60 y s., citado por Lanza, A.: "La Questione del Momento in cui l'Anima Razionale e Infusa nel Corpo", 1938).

${ }^{81}$ Padres Griegos, De Hominis Opificio, 44, 235. 
tenido lugar su fermentación y actuación. Califica de absurdísima la doctrina de Santo Tomás, porque obliga al hombre a pasar por las formas inferiores de planta y animal, no logra explicar el desarrollo del embrión, pues una forma inferior como la vegetal, por ejemplo, no puede organizar el cuerpo para la recepción de una forma superior; porque despedaza la unidad de la generación humana le quita todo sentido de originalidad, haciendo al feto obra de tres agentes distintos, las almas vegetal, animal y humana; porque hace que el hombre no engendre un semejante; porque se nivelarían el hombre y el animal, ya que cada cual engendraría una planta, etc.

Para Fyens, el alma humana organiza el cuerpo, es decir, forma sus órganos, mediante una potencia formativa o morfogenética propia del embrión mismo e intrínseco a él, recayendo su acción sobre una materia que tiene para su mantención y actuar una disposición rudimentaria, incipiente o incoativa, en camino a la disposición perfecta, y naturalmente ordenada a ella. Al hablar así de la materia inicial, Fyens se refiere a una organicidad incipiente ${ }^{82}$.

El parecido de los hijos con los padres se debe a que en las semillas de uno y otro hay formas cognoscitivas naturales, y algunos modelos impresos por los padres, según los cuales el alma del feto introducida en la generación, organiza, no de otra manera que como el pintor pinta según la figura del modelo puesto ante él, pudiendo el alma conocer aquellas figuras y conformar según ellas, en virtud de cierto instinto natural (pp. 187-188). La facultad formatriz puede conocerlas no con verdadero conocimiento, sino sólo por cierto modo natural o mero instinto (p. 194); por un conocimiento impropiamente dicho, que no es otro que el del instinto, por el cual también las plantas conocen el alimento, tomando el útil y desechando el inútil (p. 196). Este conocimiento sólo por metáfora y por falta de nombre es llamado tal (p. 196.) De qué modo aquellas imágenes hagan su representación a la facultad formatriz, y "de qué modo la formatriz la comprenda y conozca, es algo que hay que dejar entre los arcanos y cosas inescrutables de la naturaleza: y en ello hay que ver ya la excelencia y divinidad de la

${ }^{82}$ Según Fyens, el alma para organizar el cuerpo fabrica sus órganos; para ello no usa órganos que sean partes del cuerpo; opera, sin embargo, con otros órganos materiales, o sea espíritus (en el sentido de substancias materiales al servicio de una facultad), temperamento, calor nativo, que son cualidades e instrumentos materiales (p. 151), "y otras condiciones y cualidades mucho más nobles existentes en la semilla (semen) y acaso desconocidas para nosotros" (p. 150). O sea, para Fyens, el embrión tiene al principio una organicidad básica a partir de la cual el alma fabrica y construye los órganos propios del individuo desarrollado, verdad que ha venido a confirmar la biología actual con el conocimiento del genoma. 
formatriz, ya la inmensa majestad de Dios autor de la naturaleza" (pp. 196$197)^{83}$.

No podemos dejar de observar que estas formas cognoscitivas naturales de que habla Fyens, impresas por los padres en sus semillas, vienen a ser en cierto modo y en substancia el genoma, y que esa capacidad de la facultad formatriz - hoy diríamos morfogenética - de conocer, metafóricamente hablando, tales modelos impresos por los padres, viene a ser la capacidad de "leer" el código genético con que hoy se sabe cuenta el embrión, todo entrevisto por pura deducción lógica. Hay que reconocer que el hallazgo no puede ser más impresionante ${ }^{84}$.

vii) Pablo Zacchia (1583-1658), protomédico del Papa Inocencio X, quien sostiene que es absurda la doctrina aristotélica de la sucesión de almas, que la formación de los órganos no puede llevarla a cabo sino un factor intrínseco, que es una operación vital, que no puede por tanto depender sino del alma humana, y que ésta cuenta para realizarla con un órgano o instrumento que es el espíritu gaseoso del semen de que habla Aristóteles $^{85}$.

38. Entre los autores actuales, en el campo del tomismo, ya con conocimiento de la biología moderna, defienden esta doctrina Emilio Navarro Rubio, médico y filósofo, en su importantísima obra El Momento de la Unión del Alma con el Cuerpo ${ }^{86}$, Benedict Ashley, que señala como

83 "Quomodo autem illam faciant et quomodo formatrix comprehendat ac agnoscat eam, in arcanis ac inescrutabilibus naturae est relinquendum: in eoque et formatricis excelentia ac divinitas et Dei naturae authoris immensa maiestas sunt suspiciendae".

${ }^{84}$ El médico obstetra y profesor de Bioética italiano Salvino Leone dice que en Fyens no se puede no ver "una límpida intuición de orden biológico". "Fyens, en efecto, identifica en estos tres días el momento en el cual 'las dos semillas' se unen y se verifica su 'actuación' (en el fondo, aquella que nosotros hoy llamaríamos 'fusión de los dos pronúcleos'). No sólo esto, sino que su intuición sigue más allá, hasta entrever la demostración de la transmisión hereditaria de los caracteres. El semen de los padres, en efecto, contaría con imágenes que serían de alguna manera reproducidas por el alma guiada por un instinto divino 'de modo no diverso a cuanto hace el pintor cuando pinta un objeto según la imagen del modelo'. Como se ve, estamos frente a una 'pintoresca' —es el caso de decirlo- así como genial intuición de la síntesis proteica consiguiente a la lectura del código genético" (Leone, Salvino: "Le Antiche Radici di un Recente Dibattito", 1998, pp. 48-49). Compartimos la apreciación del Profesor Leone en cuanto a la intuición biológica de Fyens, si bien creemos que toma indebidamente al pie de la letra - acaso- el simil del pintor con su arquetipo, que sólo puede entenderse debidamente teniendo en cuenta lo que Fyens dice más adelante, en el sentido de que el conocimiento que la facultad formativa tiene de las "imágenes" impresas en los gametos es llamado tal sólo en forma metafórica, y a falta de otro nombre, y que se compara al que permite a las plantas conocer su alimento y desechar lo inútil. Es como cuando ahora hablamos de un edificio "inteligente", o de la "lectura" del código genético, o de instrucciones para un computador.

${ }^{85}$ Pauli Zacchiae Romani: Quaestiones Medico-Legales [1751], T. II, Venecia, L. IX, tít. I, p. 194 y ss.

${ }^{86}$ Navarro Rubio, Emilio: El Momento de la Unión del Alma con el Cuerpo, 1957. 
órgano formador del resto de los órganos el núcleo de la célula ${ }^{87}$; Rudolph Gerber, quien sostiene que el requisito del cuerpo de ser orgánico o tener órganos para estar informado por el alma humana se satisface con el genotipo, que constituye estructura humana, porque a través del ADN la entidad está determinada a un desarrollo específicamente humano hasta llegar a ser un adulto humano 88 ; Francis Wade S. J., quien argumenta que "la tendencia natural a pensar y a elegir es básica para el ser del feto y las tendencias biológicas (las más claramente activas en el genotipo) son sólo especificaciones de la tendencia radical a devenir un ser pensante" 89 .

Apartándose del sistema aristotélico-tomista en cuanto rechaza prácticamente la teoría hilemórfica, el médico y filósofo belga Philippe Caspar sostiene sin embargo la doctrina que exponemos a base de la individualidad biológica y organicidad del cigoto ${ }^{90}$.

Podemos en este recorrido citar también a Xavier Zubiri, para el cual el cigoto es ya persona humana:

\begin{abstract}
El germen — dice- es ya un ser humano. Pero no como creían los medioevales (y los medioevalizantes que muchas veces ignoran serlo), porque el germen sea germen de hombre, sino porque el germen es un hombre germinante, y, por esto, es "ya" formalmente y no sólo virtualmente hombre. La germinación es ya formalmente humana. A mi modo de ver, en el sistema germinal, además de sus notas físico-químicas, están todas sus notas psíquicas, inteligencia, sentimiento, voluntad, etc. [...]. El sistema germinal, pues, es ya el sistema sustantivo humano integral. La célula germinal es ya "célula-de" esta psique, y esta psique es ya "psique-de" esta célula ger$\operatorname{minal}^{91}$.
\end{abstract}

Por último podemos citar al filósofo chileno Alfonso Gómez-Lobo, profesor de Metafísica y Filosofía Moral en la Universidad de Georgetown y miembro del Comité de Bioética del Presidente Bush, de los Estados

${ }^{87}$ Ashley, Benedict: "A Critique of the Theory of Delayed Hominization", 1976, apéndice 1, pp. 123-124, citado por Heaney, Stephen J.: "Aquinas and the Presence of the Human Rational Soul in the Early Embryo", 1992, pp. 34-35.

${ }^{88}$ Gerber, Rudolph: "When is the Human Soul Infused?", 1966, pp. 245-246, citado por Heaney, Stephen: "Aquinas and the Presence of the Human Rational Soul in the Early Embryo", 1992, p. 34.

${ }^{89}$ Wade, S. J., Francis: "Potentiality in the Abortion Discussion", 1975, pp. 239-255, citado por Heaney, Stephen: "Aquinas and the Presence of the Human Rational Soul in the Early Embryo", 1992, p. 34.

${ }^{90}$ Caspar, Philippe: La Saisie du Zygotte Humain par l' Esprit, 1987, p. 336 y ss., a propósito del rechazo del hilemorfismo; y Caspar, Philippe: Penser l' Embryon d' Hippocrate á Nos Jours, 1991, pp. 107-108.

${ }_{91}$ Zubiri, Xavier: Sobre el Hombre, 1986, pp. 49-50, citado por Bellver Capella, Vicente: “¿Clonar? Ética y Derecho ante la Clonación Humana”, 2000. 
Unidos de Norteamérica, quien puede ser presentado como partidario de la tesis de la facultad de autoconstrucción inherente al embrión:

En las últimas décadas, algunos filósofos han defendido una distinción entre ser humano y persona en virtud de la cual comenzamos nuestra vida como seres humanos en sentido biológico, que no merecen respeto, y llegamos a ser personas dignas de respeto mucho después. ¿Cuándo? Todavía no hemos oído una respuesta unívoca ni basada en ningún hecho verificable. Lo importante es que esta distinción permite justificar cualquier manipulación de embriones humanos y, por cierto, la clonación. Mi posición es que la evidencia empírica apunta más bien al hecho de que cada uno de nosotros es un organismo que se desarrolla uniformemente desde la fertilización del óvulo materno y sin grandes sobresaltos biológicos. Las funciones superiores y el uso de la razón emergen paulatinamente en un organismo cuya identidad se extiende en el tiempo. No somos personas a partir de una determinada fase de nuestra existencia, sino que somos personas desde el comienzo, pues llevamos dentro la información biológica que lleva al desarrollo de las funciones que asociamos con las personas adultas. En el mundo circundante "ser humano" y "persona" son predicados coextensivos ${ }^{92}$.

\section{II.b.6. Derivaciones actuales deformantes de la doctrina de Santo Tomás}

39. Hay quienes hallándose al corriente de la biología actual siguen sosteniendo la doctrina de Santo Tomás - lo que, dicho sea con todo respeto, es como seguir sosteniendo que la tierra es plana después de los viajes de Colón y Magallanes-, pero con una deformación gravísima, por cuanto le quitan el punto esencial que permitía a Santo Tomás mantener el concepto de generación. Tal deformación consiste en suprimir el concepto de la virtud o potencia formativa dependiente del alma del padre. Tal es el caso de Lanza, cuya obra sin embargo es básica por su documentación y acuciosidad en la parte histórica, para el cual tal virtud formativa debe reemplazarse por las propias almas vegetal y animal transitorias ${ }^{93}$. También el Padre Joseph Donceel S. J. decide abandonar la virtud formativa dependiente del alma del padre para reemplazarla por la capacidad que tendría lo que existe de producir nuevos seres, según un supuesto nuevo concepto de "transformación creativa" que sería intermedio entre los conceptos de creación y transformación ${ }^{94}$.

${ }^{92}$ Gómez-Lobo, Alfonso: Entrevista concedida a don Pedro Pablo Aldunate B., El Mercurio, Santiago, 3 de febrero de 2002, “Artes y Letras", E 7.

${ }^{93}$ Lanza, A.: "La Questione del Momento in cui l'Anima Raciónale e Infusa nel Corpo", 1939, p. 249 y ss.

${ }^{94}$ Donceel, S. J., Joseph: "Immediate Animation and Delayed Hominization", 1970, pp. 84-85. 


\section{REFERENCIAS BIBLIOGRÁFICAS}

Alberts, Bruce y otros: Molecular Biology of the Cell. Nueva York, Londres: Garland Publishing Inc., $3^{\mathrm{a}}$ edición, 1994.

Aristóteles: Del Alma.

Aristóteles: Generación de los Animales.

Aristóteles: Historia de los Animales.

Ashley, Benedict: "A Critique of the Theory of Delayed Hominization". En D. G. Mc-Carthy y A. S. Moraczwski (eds.), Ethical Evaluation of Fetal Experimentation: An Interdisciplinary Study. St. Louis: Pope John XXIII Medical-Moral Research and Education Center, 1976.

Austin, C. R.: "The Significance of Fertilization". Archivos de Biología y Medicina Experimentales, 23; 13-15, 1990.

Barbado, Manuel: “¿Cuándo se Une el Alma al Cuerpo?” En Filosofía, enero-marzo 1943, Madrid.

Basso O. P., Domingo: Nacer y Morir con Dignidad. Bioética. Buenos Aires: De Palma, 1991.

Bellver Capella, Vicente: ¿Clonar? Ética y Derecho ante la Clonación Humana. Granada: Editorial Comares, 2000.

Boecio: De Duabus Aturis et una Persona Christi.

Caspar, Philippe: La Saisie du Zygotte Humain par l' Esprit. París: Ediciones P. Lethielleux, Le Sycomore, 1987.

Caspar, Philippe: Penser l' Embryon d' Hippocrate á nos Jours. París: Penser la Vie, Editions Universitaires, 1991.

Davis, E.: Carta al director de la revista Nature. Nature, $\mathrm{N}^{\circ}$ 320, 20 de marzo de 1986.

Donceel S. J., Joseph: "Immediate Animation and Delayed Hominization". En Theological Studies, 31 (1970).

Fyens, Tomás: De Formatione Foetus Liber, in quo Ostenditur Animam Rationalem Infundi tertia Die. Antuerpiae (Amberes), 1620.

Ford, Norman M.: When Did I Begin? Conception of the Human Individual in History, Philosophy and Science. Cambridge University Press, 1991.

Gardner, R. C. "Le Destin des Cellules dans l'Embryon”. La Recherche, 21, 1990.

Gerber, Rudolph: "When is the Human Soul Infused?". En Laval Théologique et Philosophigue, 22 (1966).

Gómez-Lobo, Alfonso: Entrevista concedida a Pedro Pablo Aldunate B. El Mercurio, Santiago, 3 de febrero de 2002, “Artes y Letras", E 7.

Heaney, Stephen J.: "Aquinas and the Presence of the Human Rational Soul in the Early Embryo". En Thomist, 56 (1992).

Horvart y Weiss: Nociones de Biología, IV. Editorial Salesiana, 10a edición, 1984.

Jenkins, John B.: Genética. Barcelona: Editorial Revertés A., 1986.

Kahn, Axel: “Quelle Dignité pour l'Embryon Humanin?”. En B. Feuillet-Le Mintier (dir.), L'Embryon Humain: Approche Multidisciplinaire. París: Ed. Económica, 1996.

Langman: Embriología Médica. Thomas W. Sadler, ed. México: Editorial Médica Panamericana, sexta edición, 1993.

Lanza, A.: "La Questione del Momento in cui l'Anima Raciónale e Infusa nel Corpo". Bollettino Filosófico, 4 (1938) y 5 (1939).

Lejeune, Jérôme: "Genética, Ética y Manipulaciones". Conferencia editada por la Universidad Católica de Córdova, 1986.

Lejeune, Jérôme: ¿Qué Es el Embrión Humano? Madrid: Rialp, 1993. 
Lejeune, Jérôme: "Una Reflexión Ética sobre la Medicina Prenatal". En Aquilino Polaino Llorente (dir.), Manual de Bioética General. Madrid: Rialp, 1993.

Leone, Salvino: "Le Antiche Radici di un Recente Dibattito". En Pontificia Academia Pro Vita, varios autores, Identità e Statuto dell' Embrione Umano. Ciudad del Vaticano: Librería Editrice Vaticana, 1998.

Lovell, Stephen. Carta al director de revista Nature. Nature, Vol. 314, 11 de abril de 1985.

Mc Laren, A.: "Prelud to Embryogenesis". En The Ciba Foundation, Human Embryo Research: Yes or No? Londres: Tavistock Publication, 1986.

Monod, Jacques: El Azar y la Necesidad: Ensayo sobre la Filosofía Natural de la Biología Moderna. Barcelona-Caracas: Monte Ávila Editores, 1971.

Navarro Rubio, Emilio: El Momento de la Unión del Alma con el Cuerpo. Pamplona: Publicaciones del Estudio General de Navarra, 1957.

Patten: Embriología Básica. Bruce M. Carlson, ed. México: Interamericana-Mc Graw Hill, $5^{\text {a }}$ ed., 1990.

Rénard, Jean Paul: "L'Embryon in Vitro". En B. Feuillet-Le Mintier (dir.), L'Embryon Humain: Approche Multidisciplinaire. París: Ed. Económica, 1996.

Rogers, J. G., L. Voullaire, H. Gold: "Monocigotic Twins Discordant for Trisomy 21". En American Journal of Medical Genetics, 11/1982.

Rostand, Jean: El Hombre. Madrid: Alianza Editorial, 1983. [Publicación original: L' Homme. París: Ediciones Gallimard, 1941.]

Rubio Cardiel, Julián: Los Genes: Qué Son y qué Hacen en el Organismo. Madrid: Editorial Síntesis, 1989.

San Gregorio Niseno: De Hominis Opificio. Padres Griegos, 44.

San Máximo Confesor: Ambiguorum Liber. Patrología Griega, XCI.

Santo Tomás de Aquino: Suma Contra Gentiles, L. II.

Santo Tomás de Aquino: De Potentia.

Santo Tomás de Aquino: Suma Teológica, I.

Santo Tomás de Aquino: Comentario al Tratado del Alma.

Serani Merlo, Alejandro: “Análisis Antropológico-Ético de la Intervención Genética en los Primeros Estadios del Desarrollo Embrionario". Trabajo presentado al VIII Congreso de la Asociación Internacional de Facultades de Medicina Católicas.

Serani Merlo, Alejandro: "El Comienzo de la Vida Humana". En Alejandro Serani y Manuel Lavados M., Ética Clínica. Santiago: Ediciones Universidad Católica de Chile.

Serra, Angelo: "Dalle Nuove Frontiere della Biologia e della Medicina: Nuovi Interrogativi alla Filosofia, al Diritto e alla Teologia". En A. Serra, E. Sgreccia, M. L. Di Pietro, Nuova Genetica ed Embriopoiesi Umana. Milán: Vita e Pensiero, Università Catolica del Sacro Cuore, 1990.

Serra, Angelo: "Per un'Analisi Integrata dello Status dell' Embrione Umano". En S. Biolo (a cura di), Nascita e Morte dell' Uomo: Problemi Filosofici e Scientifici della Bioetica Génova: Marietti, 1993.

Serra, Angelo: "Estado Biológico del Embrión Humano: ¿Cuándo Comienza el Ser Humano?". En Pontificia Academia para la Vida (varios autores), Comentario Interdisciplinar a la "Evangelium Vitae". Madrid: Biblioteca de Autores Cristianos, 1996.

Serra, Angelo y Roberto Colombo: "Identitá e Statuto dell' Embrione Umano: Il Contributo de la Bilogia". En Pontificia Academia Pro Vita (J. Carrasco de Paula, R. Colombo, M. Cozzoli, et al.), Identitá e Statuto dell' Embrionne Umano. Librería Editrice Vaticana, 1998. 
Simerly, Calvin, Wu, Owo-Yang, Zoran, Sara y otros: "The Paternal Inheritance of the Centrosome, the Cell's Microtubule-Organising Center, in Humans, and the Implications for Infertility". En Nature Medicine, 1 (1995).

Villée, C.: Biología General. México: Interametrica, Mc Graw Hill, $7^{\text {a }}$ ed., 1992.

Wade S. J., Francis: "Potentiality in the Abortion Discussion". En Review of Metaphisics, 29 (1975) .

Zacchia, Paulo: Quaestiones Medico-Legales, t. II, Venecia, 1751, L. IX.

Zubiri, Xavier: Sobre el Hombre. Madrid: Alianza, Sociedad de Estudios y Publicaciones, 1986. 